\title{
Are digital business and digital public services a driver for better energy security? Evidence from a European sample
}

\author{
Le Thanh $\mathrm{Ha}^{1}$
}

Received: 14 September 2021 / Accepted: 25 November 2021 / Published online: 3 January 2022

(c) The Author(s), under exclusive licence to Springer-Verlag GmbH Germany, part of Springer Nature 2021

\begin{abstract}
This paper empirically analyses the impacts of the digital transformation process in the business and public sectors on energy security (ES). We employ 8 indicators to represent four aspects of energy security, including availability, acceptability, develop-ability, and sustainability. Digital businesses development is captured by e-Commerce (including e-Commerce sales, e-Commerce turnover, e-Commerce web sales) and e-Business (including customer relation management (CRM) usage and cloud usage). Digital public services development is reflected by business mobility and key enablers. Different econometric techniques are utilized in a database of 24 European Union countries from 2011 to 2019. Our estimation results demonstrate that digital businesses play a critical role in improving the acceptability and develop-ability of energy security, while digitalization in public services supports achieving energy sustainability goals. The use of modern digital technology such as big data, cloud computing is extremely important to ensure the security of the energy system, especially the availability of energy. For further discussion on the role of digital public services, we reveal a nonlinear association between digitalization in the public sector and energy intensity and energy consumption, suggesting the acceptability and develop-ability of energy security can be enhanced if the digital transformation process achieves a certain level.
\end{abstract}

Keywords Digital business · E-commerce, digital public services · Energy security $\cdot$ European countries $\cdot$ Nonlinear effects

JEL code $\mathrm{F} 21 \cdot \mathrm{G} 21 \cdot \mathrm{O} 16 \cdot \mathrm{C} 33$

\section{Introduction}

The invention of machines and equipment assists economic development by gradually replacing human labor. Since then, energy has become the most crucial aspect in keeping them running. Undoubtedly, environmental quality and energy security (ES) are important priorities in countries' economic growth strategies around the world. Even though the role of ES is undeniable, it was not until 2007 that the Asian Pacific Energy Research Centre (APERC 2007) first emphasized its role and the need to implement strategies to ensure ES. They established the definition that, if an economy is able to provide a sustainable and timely supply

Responsible Editor: Ilhan Ozturk.

Le Thanh Ha

halethanh.kt@gmail.com

1 Faculty of Economics, National Economics University, Hanoi, Vietnam of energy for its operations, and at the same time manage energy prices to ensure that development performance is not affected, that the energy system is secured. The ES is considered as an integral component of the modern world and a critical determinant of the sustainable growth of every economy (Khan and Hou 2021a, b; Khan et al. 2021b). Energy consumption leads to an improvement of revenue, job creations, and is a driving factor for obtaining sustainable growth (Dogan and Aslan 2017; Khan and Hou 2021a, b). However, Khan and Hou (2021a, b) and Khan et al. (2021b) argue that environmental degradation may be associated with a rise in energy consumption. Energy consumption results in economic growth but degrades the quality of the environment in the long run by using the global sample of 38 International Energy Agency countries (Khan and Hou 2021a). Khan et al. (2021b) content that the effects of energy consumption are conditional on the type of resource. Particularly, natural resources and renewable energy enhances environmental quality, while there presents an environmental degradation if there is a rise in demand for non-renewable energy. Hence, 
the transformation of the economy from using non-renewable energy into renewable energy is critical to ensure the path toward sustainable development.

As indicated in the literature, the ES is governed by two different groups of activities. The first group of activities includes energy preparation and distribution procedures that ensure adequate and timely supply for necessary equipment, including the physical existence of energy (available feature), the ability to pay for purchases and imports (ability pay), and access to them based on transportation systems and political ties (accessibility). The second group of activities focuses on elements that contribute to energy consumption sustainability, such as economic benefits and environmental repercussions (receivability), as well as the relationship between energy structure and carbon emissions from primary energy use (developmental capacity) and longterm development of a system using non-fossil fuels (sustainability) (Fang et al. 2018; Le and Nguyen 2019). Primary energy endowment, economic strength, and political issues have unchangeable impacts on the availability, affordability, and accessibility of ES, while other dimensions, such as the acceptability and develop-ability are conditional on technological development and behavioral changes among individuals and firms. The focus of this research is paid on the availability, acceptability, develop-ability, and sustainability of the energy system.

Traditional production, as well as human behavior perception, are gradually being reshaped by the digital economy. In a challenging time such as now, technical advancements appear to be the best measure for countries' growth. The COVID-19 pandemic causes governments to take severe measures to prevent the spread of it, which has driven global digitization up to unprecedented levels in scale and speed (OECD 2020). ES, being an essential part of growth, undoubtedly would be affected by this process. A variety of evidence demonstrates the impact of digitalization on ES. The digital platform, for example, greatly increases the management efficiency of energy systems. Alternatively, digitalization can have an impact on diverse areas of the manufacturing process, such as overall energy consumption, energy efficiency, or environmentally beneficial adjustments. The Internet and technology improvement stemming from digitalization can exalt human capital and promote technological progress since new technologies are introduced to replace the old and backward industrial structure. Consequently, they improve energy efficiency and minimize the environmental expenses of manufacturing firms (Haini 2019; Ren et al. 2021). Digitalization, as an essential factor of growth in the context of globalization, both economically and financially (Farhadi et al. 2012; Solomon and van Klyton 2020), can also raise people's awareness of the environment and climate change (Galeotti et al. 2008; Lee and Lee 2009; MartínezZarzoso and Maruotti 2011). Firms are more likely to invest in green production campaigns if there is greater awareness of the importance of green consumption in protecting the environment, not only to deal with competitive pressure but also to meet new environmental standards (European Commission 1999; International Trade Center 2001; Kennett and Steenblik 2005; Sinclair-Desgagné, 2008). More renewable energies would undoubtedly be utilized in the production process with the switch to more current industrial technologies. However, aside from the benefits, digitalization also brings several drawbacks to ES. Technological advancements can enhance the number of goods produced, but they also reduce energy prices and pose environmental risks (Salahuddin and Gow 2016; Yang and Li 2017). In fact, the literature on the impact of the Internet on energy usage is ambiguous (Huberty et al. 2011; Font Vivanco et al. 2014). Moreover, to our best knowledge, the study of Moyer and Hughes (2012) is the sole one that empirically investigates the link between ICTs and green consumption and production through changes in non-fossil energy costs.

On that foundation, we use more comprehensive measures and databases to investigate the relationship between digitalization in business and public sectors and ES. Even though several studies have shown their theoretical link in the past, we are the first to empirically examine the influence of the digital transformation process in a particular sector on various dimensions of the ES. By using eight different measures, we capture four aspects of energy security, including availability, acceptability, develop-ability, and sustainability. Development in digital businesses are captured by e-Commerce (including e-Commerce sales, e-Commerce turnover, e-Commerce web sales) and e-Business (including customer relation management (CRM) usage and cloud usage), while the development level of digital public services is reflected in business mobility and key enablers. Various techniques and empirical strategies are applied to the sample of 24 European nations spanning from 2011 to 2019. After validating the existence of cross-section dependence and stationarity of the first level-difference included variables, the digitalization-ES relationship is studied by using the panel corrected standard errors (PCSE) model. The feasible generalized least square estimates (FGLS) model is also used as an alternative to address issues arising from heteroscedasticity and fixed effects. To avoid endogeneity, all explanatory variables are lagged by one period.

Following this empirical approach, some critical findings could be conveyed here. Our study indicates that digitalization in business sectors can help directly improve the acceptability and develop-ability of energy systems. The use of modern digital technology such as big data, cloud computing is extremely important to secure the energy system, especially the availability of energy. By contrast, the empirical evidence suggests that digital public services attenuate the availability, acceptability, and develop-ability of the energy system, as thus 
play a vital role in sustainable development. The literature indicates that there are conflicting findings regarding the effects of digital public services or the implementation of electronic government (e-government) on the economy. For example, digitalization in the public sector improves the effectiveness of the public system (Bhatnagar and Singh 2010), saving time, money, and effort of citizens (Kumar and Best 2006) or helping develop a more transparent government (Heeks 1999). However, digital public services also impede the country's economic and commercial development because of the law (Smith 1978) or make corruptive behavior even more attractive (Heeks 1999). Accordingly, we believe that there may exist a nonlinear relationship between digital public service and ES. To investigate this detail, we add squared terms of variables reflecting digitalization in the public sector into the model. Our estimates demonstrate a nonlinear association between digitalization in the public sector and energy intensity and energy consumption, suggesting the acceptability and develop-ability of energy security can be enhanced if the digital transformation process passes a certain level.

Our paper makes at least two contributions to the existing literature. To our best knowledge, we are the first to empirically investigate the nexus between digitalization and the sustainable development of a nation's energy system. By using different measures to capture various dimensions of the ES and different indicators to reflect the development of the digital transformation process in the business sector and the public sector, we expect to provide a comprehensive on the influences of digitalization on the ES instead of taking one side of security of energy and environment solely as in prior studies. We highlight the importance of digitalization in the path toward sustainable development. The second novelty of this paper is to indicate the presence of a nonlinear relationship between digitalization in the public sector and the ES. In other words, digital public services only promote the ES if the digital transformation in the public sector reaches a certain level. Otherwise, the digital public services are even appeared to have adverse impacts on the ES. The findings of this research are important in the views of policymakers in selecting the strategic direction in the pursuit of sustainable development. Our findings are confirmed by strictly following the empirical econometric approach and applying the various techniques that are appropriate to the data with the presence of the cross-sectional dependence as an effort to control potential issues, such as multicollinearity, heteroskedasticity, and endogeneity.

The remainder of the paper is organized in the following manner. "Related works and hypothesis development" is a review of the related works and hypothesis development, while "Empirical methodology" introduces the model, data, and estimation method, respectively. The empirical data and discussion are presented in "Empirical results". In "Conclusions," we provide conclusions to wrap up the paper.

\section{Related works and hypothesis development}

\section{Influences of digitalization on energy efficiency}

It is affirmed that economic growth has often been attained at the expense of sustainability (Khan and Hou 2021a). While the consumption of resources promotes economic growth, it impedes environmental quality (Khan et al. 2021c). These effects of energy use on economic growth are evident in both the short run and long run (Khan et al. 2021d). Zakari and Khan (2021) also demonstrate similar evidence when they examine the influences of institutional quality and Chinese investment in Africa on energy consumption and its effects on economic growth. Energy consumption also leads to an improvement of revenue, job creations, and is a driving factor for obtaining sustainable growth (Dogan and Aslan 2017; Khan and Hou 2021a, b). In general, the literature has indicated the importance of energy consumption when multiple papers study its impacts on the various aspect of economic growth and financial development. However, previous papers have not fully exploited the determinants of energy security. For example, Le and Hoang (2021) study the effects of various types of economic sanctions on environmental performance by using the global sample of 207 countries during the 1995-2018 period. However, the role of digitalization and its impacts on the ES has still kept silent in the literature thus far. Furthermore, previous studies mostly concentrate on a particular dimension of energy security instead of studying it more comprehensively. Prior scholars mostly employ common measures, such as energy use (Khan et al. 2021c; Zakari and Khan 2021), energy trilemma (Khan et al. 2021c), energy transition (Khan et al. 2021b) that is a pathway toward the transformation of the global energy sector from fossil-based to low- or zero-carbon, or renewable (wind, solar, biomass, waste, hydro, and geothermal) and non-renewable (oil, natural gas, and coal) energy consumption (Khan et al. 2021a). Our study is the first attempt to fill these gaps by empirically analyzing the influence of digitalization in the business sector and public sector on the various dimensions of ES.

The prior scholars hold a similar consensus that the Internet and technology improvement stemming from digitalization can improve human capital and promote technological progress since new technologies are introduced to replace the old and backward industrial structure. Khan et al. (2021b) argue that modern economic growth plays a critical role in shifting the quantity and quality of energy from conventional non-renewables to modern renewables. Moreover, the Information and Communication Technologies (ICTs) not only help to obtain information but they also help to publish it much more effectively than before. Cloud computing and big data, as well as numerous communication channels and 
social networks, have enabled the rapid, low-cost transmission, and synchronization of information between individuals and organizations, regardless of time zone differences or geographical distance (Spiezia 2011). After being linked with the system, the data can assist employees in self-study, knowledge enhancement, research, and the development of numerous new inventions and professional abilities. As contended by Ferro (2011) and Haini (2019), technological innovation has a beneficial impact on human capital, which in turn supports faster technological transformation. As it is a cross-border system, any country can use and exploit information technology that creates the spillover impact of information to many other countries. This further increases the value of human capital and speeds up the introduction and diffusion of technology across various sectors at the international level during technological progress (Basu and Fernald 2007; Ceccobelli et al. 2012). Moreover, the support from the modern financial system is very important to promote the development of the digital world through an improvement of technological progress and an upgrade of the industrial structure. Internet platform allows for more diverse financial models and credit channels, facilitating financial transfers between investors and businesses regardless of time or spatial boundaries (Salahuddin and Alam 2016; Salahuddin and Gow 2016; Salahuddin and Gow 2016). Based on that, companies will have more resources to invest in R\&D, particularly in finding safe, efficient, costeffective, and environmentally friendly technology solutions (Faisal et al. 2018; Owusu-Agyei et al. 2020; Tamazian et al. 2009; Salahuddin et al. 2015).

Furthermore, the advancement of ICTs spawns a new form of government known as e-government, which allows online access to public information and other sorts of government public services. As the e-government model matures, it will be able to assist officials in better communicating with their constituents. From there, everyone can understand the importance of online information, interoperability, and availability of information to users, including those related to energy management and energy efficiency. E-government facilitates the collection of data for politicians. As a result, the traditional one-way information flow from the government to citizens should be turned into a twoway interaction model between the two parties between the government and the community. Government entities, not just city-level energy authorities, should make information on energy efficiency measures and audits publicly available on the Internet. Raising public awareness about issues like energy efficiency is a long and challenging process. E-government should be used by governments as a powerful support tool in its mass communication process (Heeks 2001). Additionally, by combining sources of scattered electricity generation with smart distribution systems, e-government establishes interconnected energy systems, that reduce total energy consumption and boost energy efficiency (UNECE 2020).

On the other hand, the process of specialization and synthesis gets more efficient as technology in production equipment develops. New emerging technologies enable the replacement of low-energy-efficient equipment with highenergy-efficient equipment (Airehrour et al. 2016), as well as the substitution of technology-intensive (high technical content) items with traditional products that are resourceintensive ( $\mathrm{Li}$ et al. 2019). With the new purpose of being more ecologically friendly, the manufacturing process must adapt, as well as efficient operations management. Technology assists the development of new products with higher productivity, as well as the expansion of markets while still maintaining environmental standards. Hence, the Internet paves the way for more effective spillover effects, such as from technologyproducing departments to technology-using departments, or from digital corporations to non-tech companies (Dunnewijk $\&$ Hultén, 2007). Furthermore, the resource structure must alter, with new resources for technology-intensive sectors taking precedence over traditional resource-intensive businesses because these industries are more productive. Countries must reconsider their economy's industrial structure, the proportion of technology-intensive industries, and the depletion of natural resources as a consequence of energy-intensive traditional businesses, which frequently pollute the environment (Qin et al. 2017). Due to low-cost information interchange between businesses and increased rivalry in the information technology sector, this process of industrial restructuring can be hastened (Vassileva et al. 2012). It enhances overall energy efficiency, thereby lowering energy consumption. This positive relationship has also been demonstrated in many experimental studies, such as Collard et al. (2005) for the French service sectors, Bernstein and Madlener (2010) and Ishida (2015) for the European manufacturing sectors, Takase and Murota (2004) for Japan, and Ren et al. (2021) for China.

\section{Influences of digitalization on green energy consumption and production}

Facing the imminent threat of non-renewable energy depletion, digitalization can be considered as a viable solution, as it both invents new energy technology and stimulates individuals and corporations to change their nonrenewable energy consumption habits to clean, renewable energy. There are two possible explanations. To begin with, e-commerce and e-business, both of which are products of digitization, provide impetus to promote intra-industry trade, domestic trade, and international trade by reducing delivery costs, blurring time and geographical distance, and bringing down the distinction between goods and services (Ahmedov 2020; OECD 2019; Shyla 2020). The role of the 
e-government model is the second argument. The quality of institutions is improved by applying digitalization to government governance, which reduces corruption and improves governance effectiveness. We anticipate that digitalization promotes economic growth and raises average incomes, based on the favorable effects of digitalization on human capital, economic structure, trade, and institutional quality. A highly digitalized country can be defined by people's need for well-being and environmental responsibility after its growth reaches a particular level (Galeotti et al. 2008; Lee and Lee 2009; Martínez-Zarzoso and Maruotti 2011). Individuals with a high level of knowledge are more likely to make more requirements on the products that they consume, such as environmental standards and the level of fossil fuels. Firms also become aware of the need and benefits of transforming their manufacturing sector toward minimizing the possible impacts on the environment or to satisfy stricter environmental standards. The firm's products become more competitive and socially acceptable if this criterion is met (European Commission 1999; International Trade Centre 2001; Kennett and Steenblik 2005; Sinclair-Desgagné, 2008). Furthermore, the introduction of environmentally friendly technology would encourage the use of "green" capital goods (with low environmental effect) instead of "brown" capital goods (Kemp-Benedict 2014), i.e., consumption of more non-fossil fuels, especially using renewable energy in the manufacturing sectors. Another advantage of e-government is that it eliminates information asymmetry, promoting green production and consumption through the spillover effects of research and development information. Global supply chains alter to adapt to the trend of green technology, which reduces the use of fossil fuels, in the context of globalization in all disciplines, including economics and finance. Cross-border exchange flows of ecological products and FDI flows are key contributors to this transformation (Bakhsh et al. 2017; Berkhout and Hertin 2001; Bi et al. 2015; Franco and Marin 2015; Haider Zaidi et al. 2019).

In addition to the demand side, from the supply-side perspective, Moyer and Hughes (2012) suggest that digitalization stimulates green consumption and production by lowering the cost of renewable energy. More specifically, the modern smart grid system is regarded as a type of energy infrastructure, whose primary function is to continuously and efficiently monitor the interaction of energy supply and demand to maximize transmission effectiveness, detect and handle errors in real time, and lower renewable energy production and consumption costs. This architecture also permits direct transactions through the electricity system. As the modern world progresses, the successes of the digital world bring in a slew of new equipment and energy, resulting in faster growth. Because the conditions for the production, distribution, and integration of renewable energy into the system will change, the energy structure will also change, with the share of renewable energy steadily increasing to replace fossil energy (Verma et al. 2020). Furthermore, advanced-algorithm pre-programmed machines and other AI technologies will rapidly promote decentralization of energy systems, enhance the reliability of weather predictions, analyze and predict consumer trends, ultimately increase technology performance, foster effective engagement of value chain members, finally encourage active participation of pro-consumers (who are consumers and producers of renewable energy).

Based on our discussion, we hypothesize:

H1: Digital business positively influences energy security.

H2: Digital public services positively influence energy security.

\section{The nonlinear effects of digital public services}

Digital public service has two opposing sides. Even though it has been proved to have numerous advantages, not all its impacts on development are positive. Due to the interaction between technology, society, and the economy, digitalization can have a variety of negative consequences for energy security. The "rebound effects" of e-government, for example, can be seen in its impact on economic growth, trade, financial development, energy effectiveness, and green innovation. In this section, we argue that digital public services (or e-government) have both positive and negative impacts on institutional quality, which are vital determinants of sustainable development (Castro and Lopes 2021).

Regarding the relationship between digital public services and institutional quality, the higher the level of e-government development, the more efficient the entire management becomes. E-government can improve its accountability by making its operations more transparent (Bertot et al. 2010), or by making such actions public and visible to the public (Ahn and Bretschneider 2011). It also helps reduce unnecessary delays in the enforcement of government laws and regulations, improving public administration efficiency. According to Maniatopoulos (2005), e-government enhances collaboration among public administration professionals. Maniatopoulos (2005) demonstrates how the e-procurement technology used by the UK's local government has increased collaboration between government departments dramatically (Jennings and Ewalt 1998). The three most important aspects of government governance are transparency, accountability, and coordination (Mooney 1947). By enhancing each of them, e-government can increase government management efficiency, lowering corruption dramatically.

However, e-government also has a number of drawbacks. As argued by prior studies, e-government is making corruptive behaviors even more attractive. As previously stated, 
corruption in the judicial process can destabilize the distribution of power among diverse factions, thus negatively impacting a country's development efforts (Lehne et al. 2018). When ministers engaging in corruption oversee the implementation of these laws, the ubiquitous presence of corruption in the executive might modify the order in which existing laws are executed (Huber and Martinez-Gallardo 2008). The presence of corruption in the judiciary, according to Smith (1978), impedes the country's economic and commercial development because the law, including its application, is not guaranteed to be equitable for all.

Despite the introduction of e-government, Saxena (2017) revealed that corruption is still rampant after surveying more than 200 Indian individuals. Residents of the city have also expressed their dissatisfaction with the expense of using government services, which has risen in tandem with the inefficiency of the operation. Autocracy is still a concern, and corruption is still increasingly prevalent. There is no evidence that e-participation reduces corruption or enhances government quality in non-democratic countries (Linde and Karlsson 2013).

As discussed by Castro and Lopes (2021), the institutional system plays a critical role in securing the energy system and ensuring sustainable development. Due to the ambiguous effect of digital public services on institutional systems, there is an ambiguous influence of this form of digitalization on energy security. When the negative effects outweigh the positive ones, digital public services may adversely influence energy security. However, this effect will reverse when the positive effects become stronger than the negative.

Based on our discussion, we hypothesize:

H3: There exists a nonlinear effect of digital public services on energy security.

\section{Empirical methodology}

The model used to investigate the nexus of digitalization and energy security (ES) can be presented as follows: develop-ability, and sustainability to investigate the effects of digitalization in the business and public sector on energy security:

- Availability: The availability is captured by a ratio of total primary energy production to total primary energy consumption (ES1), and primary energy production per capita (ES2). The data used to compute ES1 and ES2 is sourced from International Energy Statistics of the U.S. Energy Information Administration (U.S.EIA).

- Acceptability: The acceptability is reflected by a country's energy structure, as measured by the ratio of nonfossil energy consumption to total energy consumption (ES3), and the energy intensity level of primary energy (ES4). The ES3 measures the acceptability of energy security by reflecting the impact of its production and use on the economy and the environment (Fang et al. 2018). As indicated by Le and Nguyen (2019), non-fossil energy consumption promotes economic growth in both low- and high-income countries. The development of non-fossil energies will enhance the country's energy supply capacity as well as improve the sustainability of the energy system (Fang et al. 2018), thus the ES3 is considered as a positive indicator of energy security (Le and Nguyen 2019). The higher this ratio, the better because it indicates lower non-renewable energy use, which means higher energy security. Both data for ES3 and ES4 are taken from the U.S.EIA.

- Develop-ability: The develop-ability is captured by the rate of energy consumption per capita (ES5), the ratio of $\mathrm{CO}_{2}$ emissions to GDP (ES6), and the ratio of $\mathrm{CO}_{2}$ emissions to primary energy consumption (ES7). The ES5 variable measures the rate of energy consumption per capita. According to Fang et al. (2018), the ability to assess the development potential of energy security shows the sustainable development of the energy system in an optimal, clean, and low-carbon way (Fang et al. 2018). The higher level of ES5 implies the risk of the energy security system; thus, it appears to be a negative indicator of energy security. The ES5 and ES6 reflect the develop-ability of energy security (Le and Nguyen 2019). They show the link between energy

$E S_{i t}=\beta_{0}+\beta_{1} D T_{i, t}+\beta_{2} \mathrm{GDP}_{i, t}+\beta_{3} \mathrm{TRADE}_{i, t}+\beta_{5} \mathrm{FDI}_{i, t}+\beta_{5} \mathrm{CAP}_{i, t}+\beta_{6} \mathrm{INDUS}_{i, t}+\varphi_{t}+\omega_{i}+\varepsilon_{\mathrm{ijt}}$,

where $i$ and $t$ respectively represent country $i$ and year $t$. $\varphi_{t}$ and $\omega_{i}$ are added into the model to capture the country and year fixed effects, and $\varepsilon_{\mathrm{ijt}}$, is the error term.

\section{Energy security}

This paper uses eight indicators to capture the four dimensions of energy security, including availability, acceptability, structure and carbon emissions from oil, gas, and coal combustion. Carbon emission negatively influences energy security.

- Sustainability: Lastly, sustainability is captured by ES8, which is renewable energy consumption as the share of renewable consumption to the total final energy consumption. Differ from ES3 capturing the acceptability of energy security, ES8 only considers the specific renew- 
able energy consumption. According to the U.S.EIA, energy sources can be categorized into renewable, nonrenewable, and fossil fuels. Renewable energy includes biomass (wood biomass; municipal solid waste; landfill gas and biogas; ethanol; biodiesel), hydroelectric power, geothermal, solar, and wind that we predict that it can affect the sustainability of energy security, while fossil fuels consist of petroleum, natural gas, and coal. ES1 covers ES8, hydroelectric power, and other types of energy like nuclear power. There has been a continuous argument on the effects of hydroelectric power, nuclear power on the sustainability of energy security (Lee et al. 2016). As indicated by the U.S.EIA, the environmental influences of nuclear energy are more complex compared to other clean or renewable energy sources. Although nuclear power does not produce less air pollution or carbon dioxide than fossil energy, the process of mining and refining uranium ore and making reactor fuel requires a huge amount of energy. There is also a large amount of metal and concrete that also require a huge amount of energy to manufacture. A huge amount of energy consumption is directly related to pollution and carbon dioxide emissions. Regarding nuclear power, this type of energy potential potentially creates environmental contamination and long-time radioactive hazard. Indeed, nuclear energy has complicated safety and security features. To capture more precisely the sustainability of energy security, we only consider the effects of renewable energy sources in ES8.

Digital transformation (DT):the DT consists of digital business (eBUSS) and digital public services $(e G O V)$.

- Digital business: Digital business includes e-Commerce sales (eCOM_Sales), e-Commerce turnover (eCOM_ Turn), e-Commerce web sales (eCOM_Web), and e-Business, including customer relation management (CRM) usage (eBUSS_CRP) and cloud usage (eBUSS_Cloud). These variables are available from the Euro Statistics (Eurostat) covering the 2011-2019 period.

- Digital public services: Our key explanatory variable, $e G O V$, consists of two relevant indicators that reflect different aspects of digitalization in public sectors, including business mobility ( $\left.e G O V_{-} B M\right)$ and key enablers $\left(e G O V \_K E\right)$. More specifically, $e G O V \_B M$ captures the extent to which public services that are aimed at foreign businesses are available online, usable, and implement eID and eDocument capabilities. This indicator is calculated as a weighted average of business mobility online availability, usability, eID cross borders, and eDocuments cross borders. The $e G O V \_K E$ captures the extent to which technical pre-conditions for e-Government service provision are used. The key enablers used for measuring the quality of the services to businesses and citizens include electronic identification (eID), electronic documents (eDocuments), authentic sources, and digital posts. We take the data for e-Government from the e-Government benchmarking report and studies for digitalization conducted by Capgemini. The dataset is available from 2012 to 2019.

\section{Control variables}

Following the previous studies, especially Le and Nguyen (2019), we consider the effect of income level (GDP) as measured by real gross domestic product per capita, the trade value (TRADE), net foreign direct investment (FDI) inflow as measured by its share of GDP, degree of industrialization (INDUS) as measured by the value-added of the industry sector as a percent of GDP, and the gross capital formation per capita (CAP). Yang and Khan (2021) also highlight the impacts of industry value-added and capital formation in improving environmental sustainability. We collect the above variables from World Development Indicators (WDI). Besides, we collect the level of government effectiveness (GE) from WBGI. After removing the countries that have a gap and missing observations in the data, our final sample consists of 24 European countries from 2011 to 2019. Table 1 provides a detailed description of all included variables. The correlation matrix between all variables displayed in Table 2 shows the relationship between digitalization and energy security measures.

From the econometrics perspective, we conduct a test for cross-sectional dependence by applying the cross-sectional dependence (CD) method suggested by Pesaran (2021). We then use the Im-Pesaran-Shin unit root test developed by Im et al. (2003) to check the stationarity of the data presence of the CD. We present the results in Table 3. The results reveal that except for the FDI and GE, there is a cross-sectional dependency among involved variables.

According to Beck and Katz (1995) and Canh et al. (2021), along with proving the existence of $C D$ as well as the stationarity of first-difference variables, the panel corrected the standard error (PCSE) is the pertinent method. Hence, we select the PCSE model to perform the empirical analysis for our sample. A similar approach can be found in the study of Zakari and Khan (2021). All the explanatory variables are lagged by one period as presented in Eq. (1) to address the endogeneity stemming from the simultaneous relationship between e-government and energy security. To control for the issue of country differences in the sample, we drop any country that was considered as an "outlier" because of significant differences from the remaining countries. We also carefully control for both the country and year fixed effects when we run the PCSE model. To ensure the accuracy of our findings, we further perform separate models, such as 
Table 1 Description of variables

\begin{tabular}{|c|c|c|c|c|c|c|c|c|}
\hline Variable & Definition & Measure & Source & Obs & Mean & $S D$ & Min & $\operatorname{Max}$ \\
\hline ES1 & $\begin{array}{l}\text { Energy security } 1 \\
\text { (availability of energy security) }\end{array}$ & $\begin{array}{l}\text { primary energy production/primary } \\
\text { energy consumption }\end{array}$ & U.S. EIA & 144 & 0.90 & 0.36 & 0.04 & 1.94 \\
\hline ES2 & $\begin{array}{l}\text { Energy security } 2 \\
\text { (availability of energy security) }\end{array}$ & $\begin{array}{l}\text { Primary energy production/popula- } \\
\text { tion (Kg/person) }\end{array}$ & U.S. EIA & 144 & 4.24 & 3.42 & 0.24 & 18.28 \\
\hline ES3 & $\begin{array}{l}\text { Energy security } 3 \\
\text { (acceptability of energy security) }\end{array}$ & $\begin{array}{l}\text { Non-fossil energy consump- } \\
\text { tion }=1 \text {-fossil energy consumption } \\
\text { to Total }(\%)\end{array}$ & U.S. EIA & 216 & 0.23 & 0.17 & 0.02 & 0.69 \\
\hline ES4 & $\begin{array}{l}\text { Energy security } 4 \\
\text { (acceptability of energy security) }\end{array}$ & $\begin{array}{c}\text { Energy intensity level of primary } \\
\text { energy (MJ/\$2011 PPP GDP) }\end{array}$ & U.S. EIA & 144 & 1.26 & 0.37 & 0.68 & 2.58 \\
\hline ES5 & $\begin{array}{l}\text { Energy security } 5 \\
\text { (develop-ability of energy security) }\end{array}$ & $\begin{array}{l}\text { Primary energy consumption/popula- } \\
\text { tion (Kg/person) }\end{array}$ & U.S. EIA & 216 & 0.00 & 0.00 & 0.00 & 0.00 \\
\hline ES6 & $\begin{array}{l}\text { Energy security } 6 \\
\text { (develop-ability of energy security) }\end{array}$ & $\begin{array}{l}\mathrm{CO}_{2} \text { emissions (kg per } 2011 \mathrm{PPP} \$ \\
\text { of GDP) }\end{array}$ & U.S. EIA & 192 & 0.27 & 0.19 & 0.06 & 0.96 \\
\hline ES7 & $\begin{array}{l}\text { Energy security } 7 \\
\text { (develop-ability of energy security) }\end{array}$ & $\begin{array}{l}\mathrm{CO}_{2} \text { emissions/primary energy } \\
\text { consumption }(\mathrm{Kg} / \mathrm{Kg})\end{array}$ & U.S. EIA & 192 & 0.00 & 0.00 & 0.00 & 0.01 \\
\hline ES8 & $\begin{array}{l}\text { Energy security } 8 \\
\text { (sustainability of energy security) }\end{array}$ & $\begin{array}{l}\text { Renewable energy consumption (\% } \\
\text { of total final energy consumption) }\end{array}$ & U.S. EIA & 216 & 0.16 & 0.15 & 0.01 & 0.68 \\
\hline eCOM_Sales & e-Commerce sales & $\begin{array}{l}\text { The share of enterprises with } \\
\text { e-Commerce sales }\end{array}$ & Eurostat & 216 & 19.48 & 7.23 & 5.00 & 39.00 \\
\hline eCOM_Turn & e-Commerce turnover & $\begin{array}{l}\text { The share of enterprises with } \\
\text { e-Commerce sales of at least } 1 \% \\
\text { turnover }\end{array}$ & Eurostat & 216 & 16.98 & 7.39 & 3.00 & 36.00 \\
\hline eCOM_Web & e-Commerce web sales & $\begin{array}{l}\text { The share of enterprises with web } \\
\text { sales (via websites, apps, or online } \\
\text { marketplaces) }\end{array}$ & Eurostat & 216 & 15.80 & 6.06 & 5.00 & 35.00 \\
\hline eBUSS_CRP & CRP & $\begin{array}{l}\text { The share of enterprises with } \\
\text { E-commerce, customer relation } \\
\text { management (CRM), and secure } \\
\text { transaction }\end{array}$ & Eurostat & 216 & 19.48 & 7.23 & 5.00 & 39.00 \\
\hline eBUSS_iCloud & The cloud usage & $\begin{array}{l}\text { The share of enterprises using Cloud } \\
\text { computing services }\end{array}$ & Eurostat & 128 & 26.93 & 15.55 & 5.00 & 70.00 \\
\hline eGOV_BM & Business mobility & $\begin{array}{l}\text { Business mobility index as a } \\
\text { weighted average of online avail- } \\
\text { ability, usability, eID cross borders, } \\
\text { and eDocuments cross the border }\end{array}$ & eGBR & 192 & 64.86 & 17.99 & 9.00 & 100.00 \\
\hline eGOV_KE & Key enablers & $\begin{array}{l}\text { Key enablers index as a weighted } \\
\text { average of eID, eDocument, digital } \\
\text { post, eSafe and single sign on }\end{array}$ & eGBR & 192 & 54.25 & 26.67 & 0.00 & 99.00 \\
\hline GDP & Real output & $\begin{array}{l}\text { The natural logarithm of real GDP } \\
\text { per capital (constant } 2010 \text { US } \\
\text { dollars) }\end{array}$ & WDI & 216 & 36.14 & 26.03 & 10.2 & 111.15 \\
\hline TRADE & Trade share & The proportion of GDP & WDI & 216 & 1.27 & 0.67 & 0.55 & 4.08 \\
\hline FDI & $\begin{array}{l}\text { Net inflow of foreign direct invest- } \\
\text { ment }\end{array}$ & The proportion of GDP & WDI & 216 & -0.01 & 0.36 & -2.92 & 1.63 \\
\hline CAP & Gross capital formation per capital & $\begin{array}{l}\text { (Gross capital formation, total)/ } \\
\text { population }\end{array}$ & WDI & 216 & 8381.52 & 6494.02 & 1483.14 & $39,587.80$ \\
\hline INDUS & Industrialization level & $\begin{array}{l}\text { The value added of the industry sec- } \\
\text { tor as a percent of GDP }\end{array}$ & WDI & 216 & 0.23 & 0.06 & 0.11 & 0.38 \\
\hline GE & $\begin{array}{l}\text { The level of government effective- } \\
\text { ness }\end{array}$ & The government effectiveness index & WBGI & 216 & 1.16 & 0.54 & 0.08 & 2.24 \\
\hline
\end{tabular}

U.S.EIA, the International Energy Statistics of U.S. Energy Information Administration; Eurostat, the European Statistics; $e G B R$, the e-government benchmarking report; WDI, World Development Indicator; FSSDA, Finnish Social Science Data Archive; WBGI, World Bank Group Indicator

feasible generalized least squares (FGLS) that is considered as an adequate method for controlling the fixed effects (Canh and Thanh 2020). Another purpose of using this alternative model is to solve the latent problem of endogeneity in Eq. (1), as argued by Gala et al. (2018) and Sweet and
Eterovic (2019). Several other explanatory variables were also added for sensitivity analysis. ${ }^{1}$

${ }_{1}$ For saving the space, the results of this analysis can be provided upon the request. 


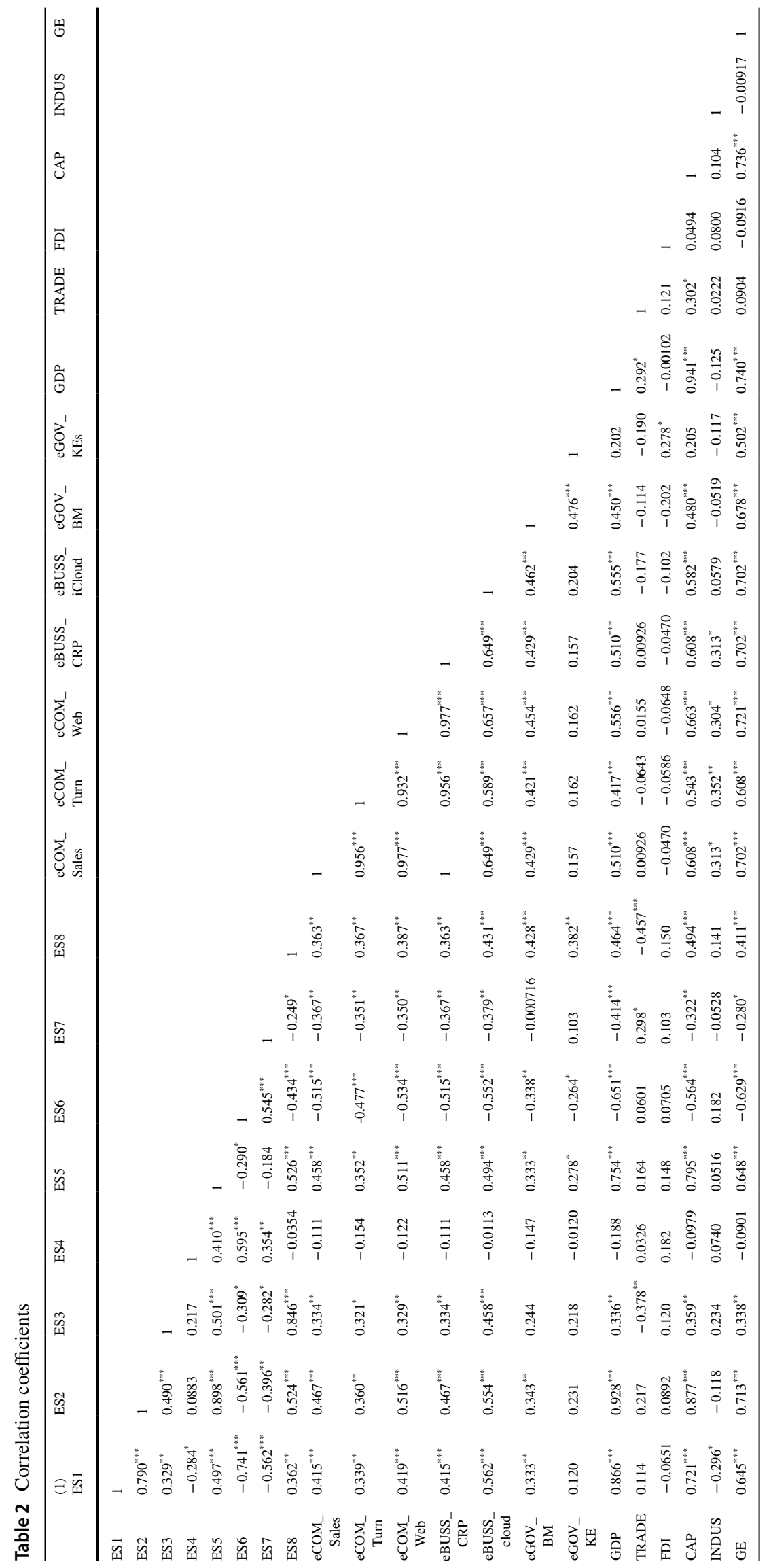


Table 3 Cross-sectional dependence tests and stationary tests

\begin{tabular}{lccll}
\hline $\begin{array}{l}\text { Variable } \\
\text { (in level) }\end{array}$ & $\begin{array}{l}\text { CD test, } \\
\text { Pesaran } \\
(2021)\end{array}$ & $\begin{array}{l}\text { Im-Pesaran- } \\
\text { Shin test } \\
(Z \text {-bar })\end{array}$ & $\begin{array}{l}\text { Variable } \\
\text { (in differ- } \\
\text { ence })\end{array}$ & $\begin{array}{l}\text { Im-Pesaran- } \\
\text { Shin test } \\
(Z \text {-bar) }\end{array}$ \\
\hline ES1 & $5.97 * * *$ & 0.89 & DES1 & $-3.39 * * *$ \\
ES2 & $6.35 * * *$ & 1.21 & DES2 & $-4.01 * * *$ \\
ES3 & $5.17 * * *$ & -1.19 & DES3 & $-3.19 * * *$ \\
ES4 & $19.79 * * *$ & 1.56 & DES4 & $-2.31 * * *$ \\
ES5 & $8.01 * * *$ & -0.85 & DES5 & $-3.11^{* * *}$ \\
ES6 & $39.92 * * *$ & $1.63 *$ & DES6 & $-2.98^{* * *}$ \\
ES7 & $43.49 * * *$ & 9.48 & DES7 & $--3.59 * * *$ \\
ES8 & $10.94 * * *$ & $-1.75 * *$ & DES8 & $-3.23 * * *$ \\
eGOV & $14.25 * * *$ & $-2.28 * *$ & DeGOV & $-2.64 * * *$ \\
GDP & $47.05 * * *$ & 3.41 & DGDP & $-2.93 * * *$ \\
TRADE & $11.54 * * *$ & 0.51 & DTRADE & $-1.34 *$ \\
FDI & 0.42 & $-2.73 * * *$ & DFDI & $--4.63 * * *$ \\
CAP & $34.73 * * *$ & 1.40 & DCAP & $--1.41^{*}$ \\
INDUS & $3.61 * * *$ & 0.15 & DINDUS & $-2.96^{* * * *}$ \\
GE & 0.86 & 0.75 & DGE & $-2.97 * * *$ \\
\hline
\end{tabular}

Regarding the CD test, the null hypothesis is that the cross-section is independent. $P$-value is closed to zero, implying that data are correlated across panel groups. Regarding the Im-Pesaran-Shin test, the null hypothesis is "Panels contain unit root" and the alternative hypothesis is "Panel are stationary"

\section{Empirical results}

\section{Baseline results}

\section{Energy security: availability}

Table 4 shows the effects of digital business and digital public service on the availability of energy security (ES1 and ES2). We found that "e-Commerce turnover" has the effect of reducing the ratio of primary energy production per population (ES2), while "e-Commerce web sales" reduces both ES1 and ES2. In contrast, the development in cloud usage will increase energy security availability through raising ES1. As for the impact on the availability of energy security from digital public service, it is most noticeable that both elements of digital public service reduce the availability of energy security. Fang et al. (2018) and Le and Nguyen (2019) contend that the ES1 shows the gap between energy supply and energy demand and the ES2 reflects a national energy supply capacity. Both are positive indicators of energy security. Our results indicate a reduction in ES1 and ES2, suggesting that both digital business and digital public service adversely affect the availability of energy systems. The findings are consistent with our prediction since the evolution of the digital economy and its spillover influences on other sectors may boost other production activities (Salahuddin and Gow 2016), which raise the demand for energy consumption. Moreover, digitalization leads to a reduction in the market price of energy use and some resources and hence, raises the demand for them among manufacturers and individuals (Yang and $\mathrm{Li}$ 2017). However, our findings also suggest the integration of modern technology (e.g., big data, cloud as...) in business can help countries to improve the energy supply capacity. As shown in columns (9) and (10), we observe the positive influence of eBUSS_Cloud on the ES1. We also find that $\mathrm{CO}_{2}$ emissions also decrease as the government's digital transformation. This finding is important since it reveals that e-business, especially the integration of modern technology in the business plays a critical role in enhancing the availability of energy systems through an improvement in energy production and reduction in energy consumption. Our findings are consistent with that of Dost and Maier (2018) and IEA (2019).

\section{Energy security: acceptability}

Regarding the acceptability of energy security, the result in Table 5 shows $e$ BUSS_Cloud has the effect of increasing non-fossil energy consumption and level intensity of primary energy. In contrast, the remaining components of digital business reduce non-fossil energy consumption and level intensity of primary energy. In other words, when digitization is put into operation, businesses depend less on energy to produce one unit of output. We also consider the effect of digital public service on the acceptability of energy security measures. The results show that both components of digital public service, business mobility ( $\left.e G O V_{-} B M\right)$ and key enablers (eGOV_KE), have the effect of increasing the level of intensity of primary energy (ES4). Our findings highlight the fact that the promotion of digital transformation in the business sector positively affects the acceptability of the energy system. Moreover, the role of integration of modern technology such as big data, cloud, into the business sector has become especially important in changing production behavior from using fossil energy to non-fossil energy. Conversely, the findings reported in columns (11)-(14) suggest that the promotion of digital public service causes detrimental effects on the acceptability dimension. However, as we argued previously, there are rebound effects of digital public services, suggesting the efficiency of digital public services appears if the implementation of this type of digitalization reaches a certain threshold. We then check this prediction in further analysis.

\section{Energy security: develop-ability}

Table 6 presents the effects of digital business and digital public services on the develop-ability of ES. The variables 


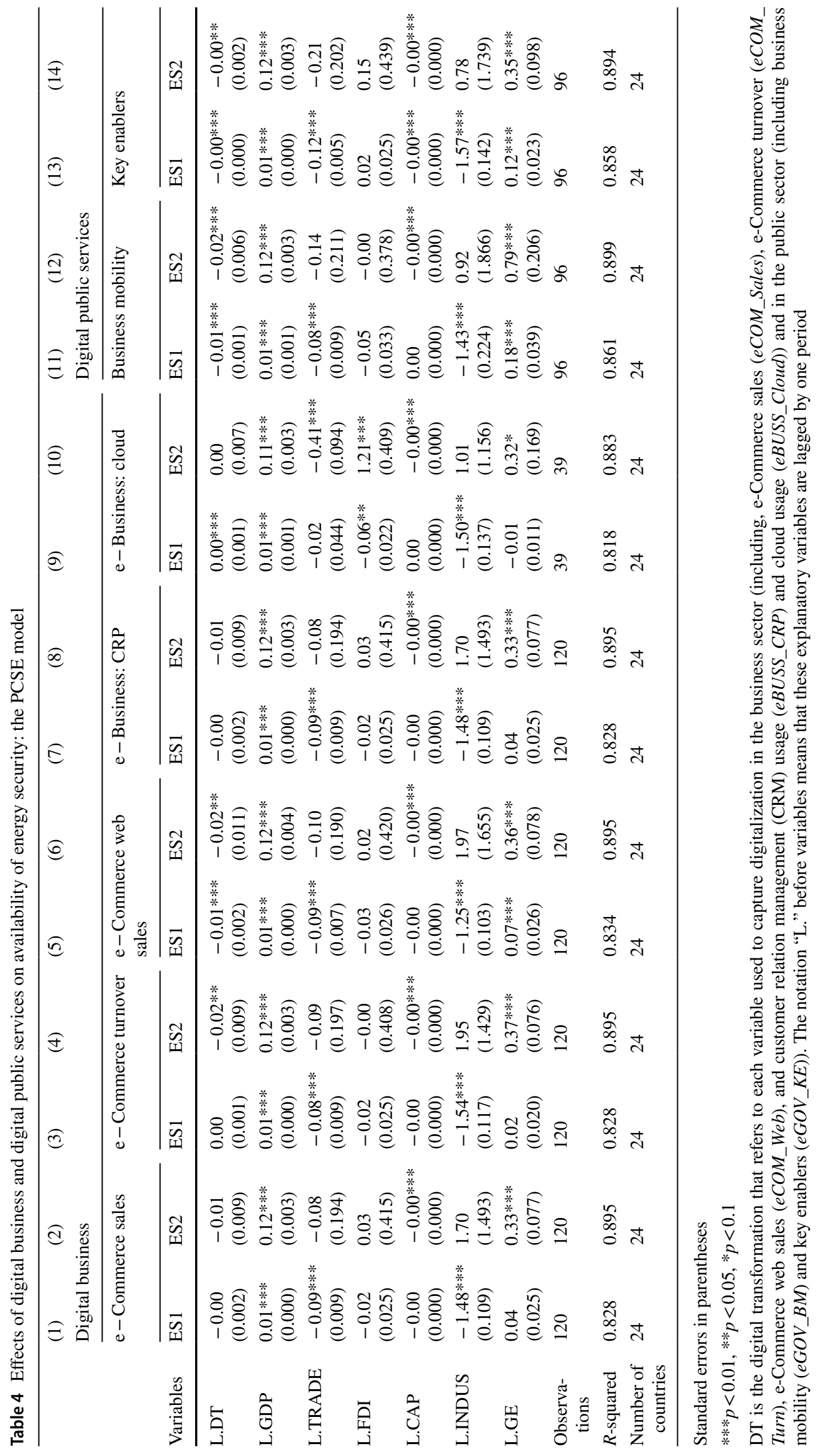




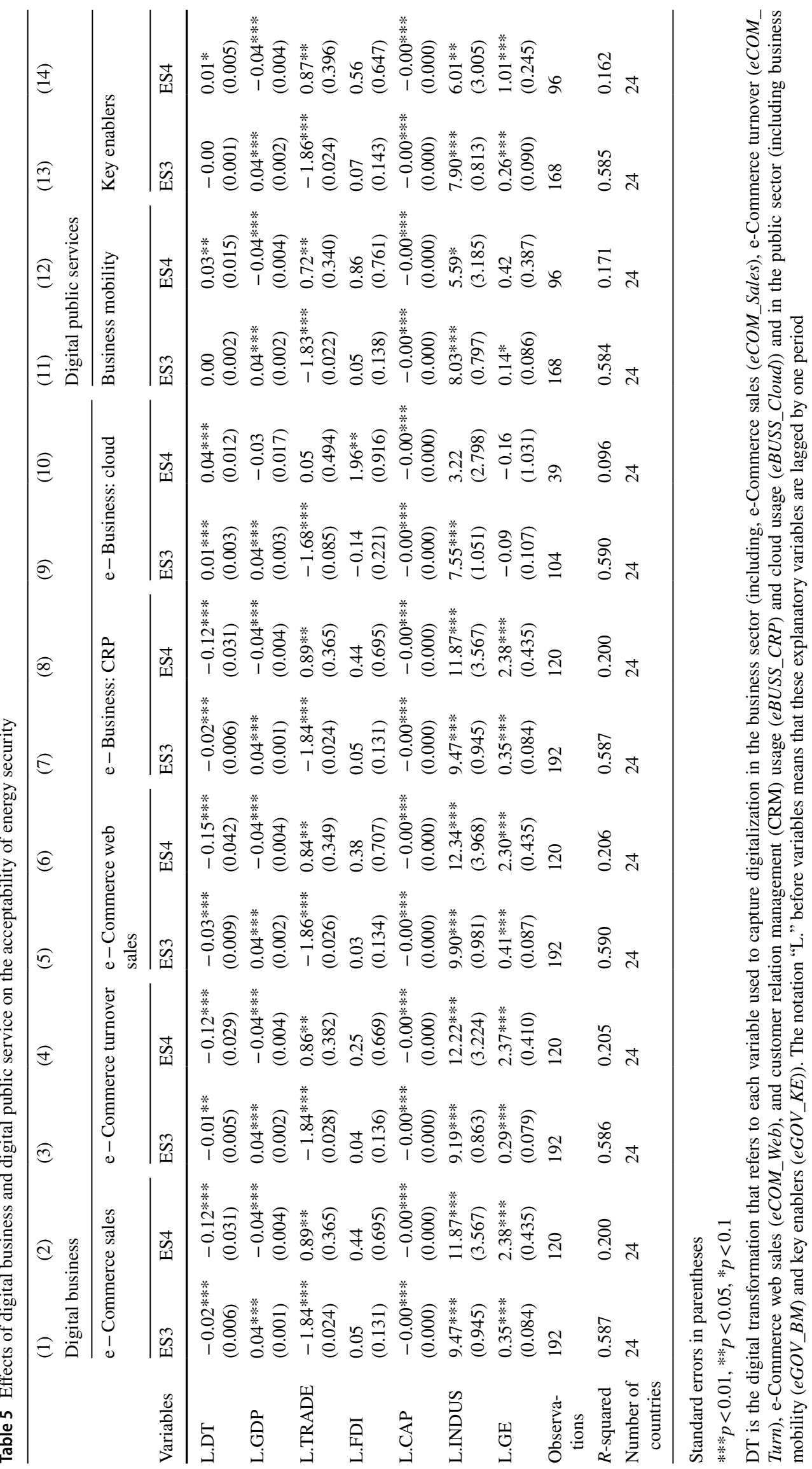




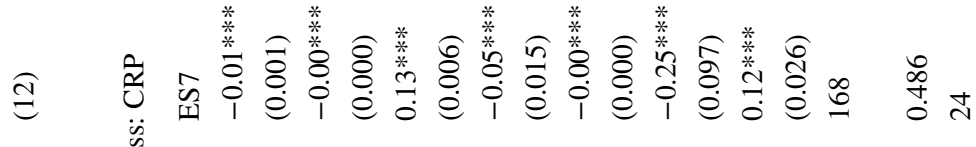

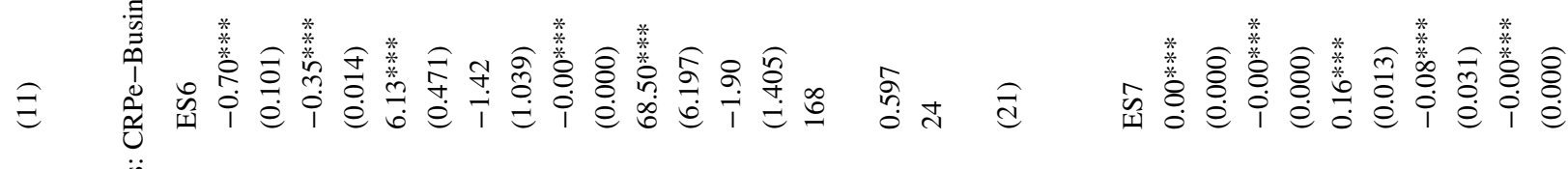

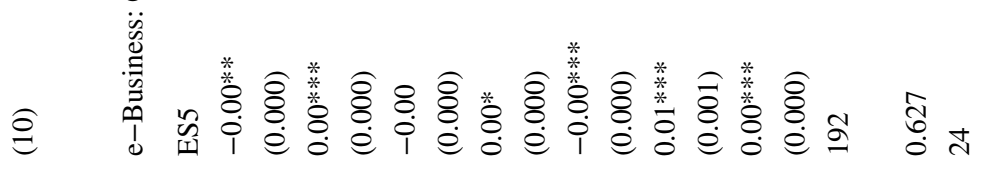

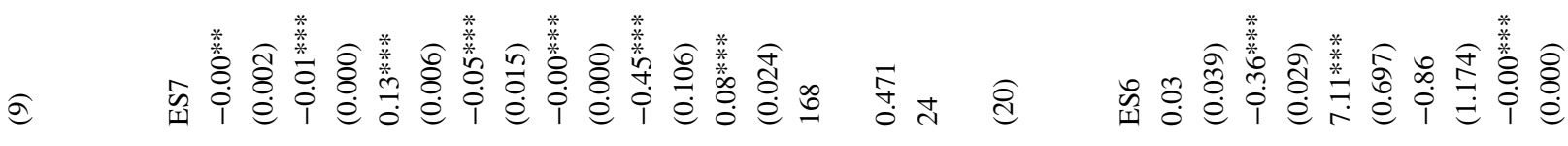

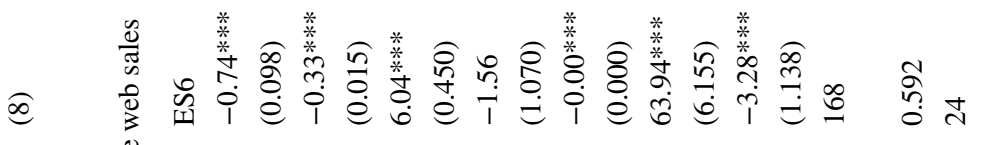

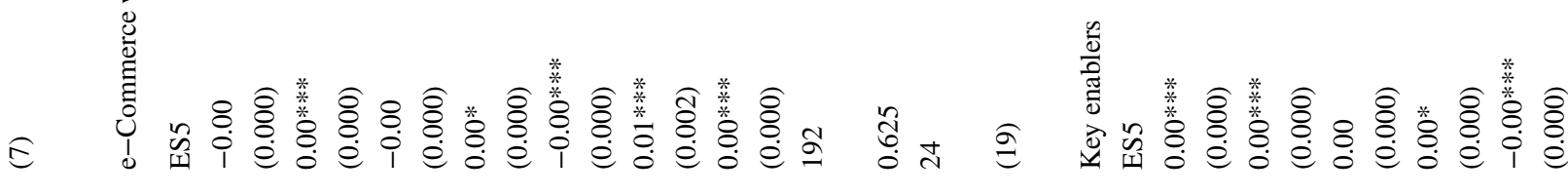

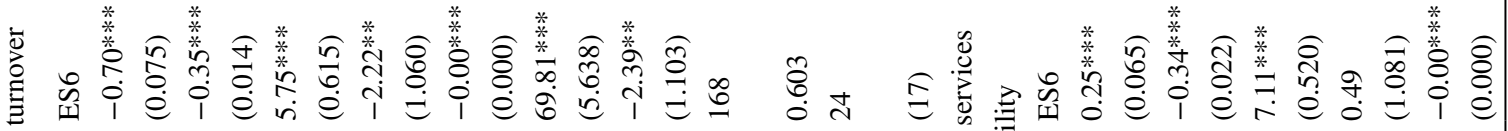
苛 * *

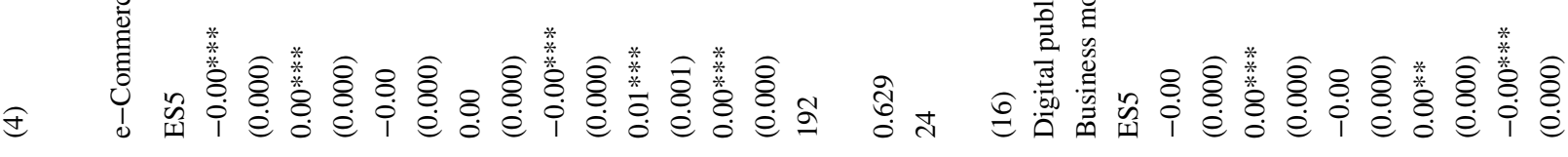

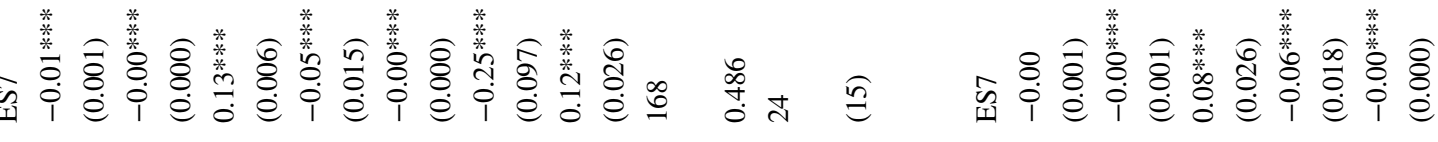
.50

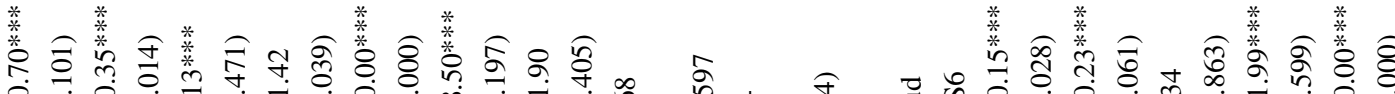

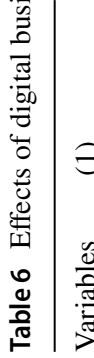

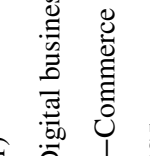
*

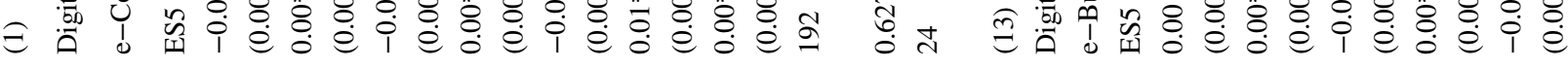

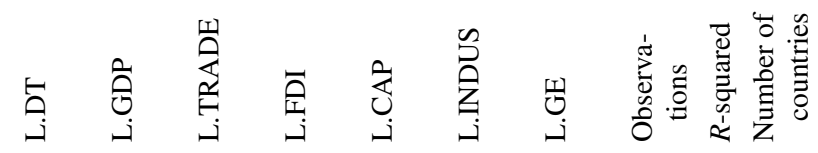

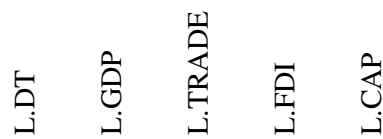




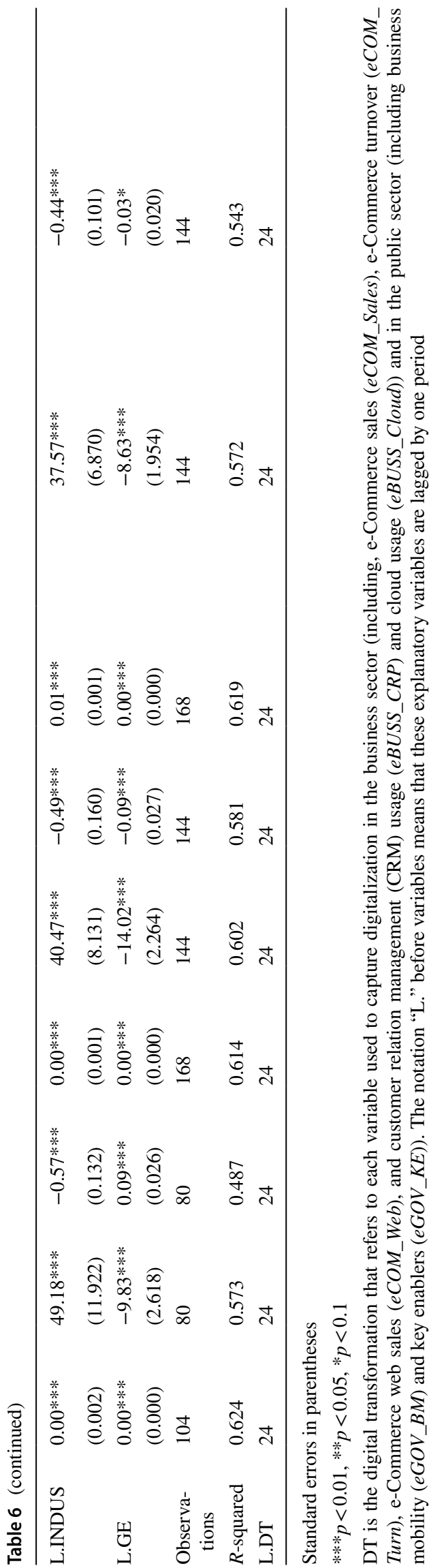

eCOM_Sales, eCOM_Turn, all have the effect of reducing the size of the variables that are positively associated with the develop-ability of ES (ES5, ES6, and ES7). Also, a rise in eBUSS_CRP reduces ES5, ES6, and ES7, while eBUSS_Cloud helps reduce ES6. The results suggest that the implementation of digital transformation into business sectors leads to a lower level of carbon emission and primary energy consumption. This could be explained by the positive influence of internet technology on human capital and financial development, which supports R\&D activities and technological progress (Ferro 2011; Haini 2019; Salahuddin and Gow 2016; Spiezia 2011). The technological advancement, in turn, creates the upgrading of industrial structure from traditional resource-intensive to technology-intensive and allow the replacement of low-energy equipment to highenergy ones as well as the development of more eco-friendly technologies (Airehrour et al. 2016; Li et al. 2019; Rent et al. 2021). This would not only enhance energy efficiency but also reduce energy intensity and carbon dioxide emissions from production activities. By contrast, digital public service negatively influences the develop-ability of ES as reported in columns 16-21. Specifically, business mobility increases ES6 and ES7 while key enablers increase ES5 and ES7. In the initial analysis, the results again suggest that digitalization in the public sector is not good for ensuring the develop-ability of ES, while the role of digital business is especially important.

\section{Energy security: sustainability}

Lastly, we investigate the effects of digitalization in the public and business sectors on the sustainability of the energy system. The estimation results are outlined in Table 7. Differ from previous findings regarding the negative impacts of digital public services on various indicators of ES, Table 7 highlights that digital public services are beneficial for sustainable economic development when they enhance the growth of economies by using more green energy rather than fossil energy sources. By contrast, all variables capturing the transformation process in the business sectors are negatively associated with the consumption of renewable energy (ES8). Our findings are consistent with Castro and Lopes (2021) and Haigh and Griffiths (2008). As revealed by Castro and Lopes (2021), the digital transformation in the public sector help promote transparency, accountability, and efficiency, then enhances sustainable and inclusive economic growth, social development, and environmental protection. Resource management also becomes more efficient if there is an availability of digital public services in the economy.

In general, the digital in business sectors can help to directly improve the acceptability and develop-ability of the energy system. The use of modern digital technology 
Table 7 Effects of digital business and digital public service on the sustainability of energy security

\begin{tabular}{|c|c|c|c|c|c|c|c|}
\hline \multirow[b]{4}{*}{ Variables } & (1) & (3) & (5) & (7) & (9) & (11) & (13) \\
\hline & \multicolumn{5}{|l|}{ Digital business } & \multicolumn{2}{|c|}{ Digital public services } \\
\hline & $\begin{array}{l}\mathrm{e}-\text { Commerce } \\
\text { sales }\end{array}$ & $\begin{array}{l}\mathrm{e}-\text { Commerce } \\
\text { turnover }\end{array}$ & $\begin{array}{l}\text { e-Commerce } \\
\text { web sales }\end{array}$ & $\begin{array}{l}\text { e-Business: } \\
\text { CRP }\end{array}$ & $\begin{array}{l}\text { e-Business: } \\
\text { iCloud }\end{array}$ & $\begin{array}{l}\text { Business mobil- } \\
\text { ity }\end{array}$ & Key enablers \\
\hline & ES8 & ES8 & ES8 & ES8 & ES8 & ES8 & ES8 \\
\hline L.DT & $\begin{array}{l}-0.23^{* * * *} \\
(0.057)\end{array}$ & $\begin{array}{l}-0.13 * * * \\
(0.045)\end{array}$ & $\begin{array}{l}-0.20^{* *} \\
(0.080)\end{array}$ & $\begin{array}{l}-0.23^{* * * *} \\
(0.057)\end{array}$ & $\begin{array}{l}-0.17 * * * \\
(0.034)\end{array}$ & $\begin{array}{l}-0.00^{* * * *} \\
(0.000)\end{array}$ & $\begin{array}{l}0.19 * * * \\
(0.036)\end{array}$ \\
\hline L.GDP & $\begin{array}{l}0.51 * * * \\
(0.013)\end{array}$ & $\begin{array}{l}0.51 * * * \\
(0.014)\end{array}$ & $\begin{array}{l}0.51 * * * \\
(0.013)\end{array}$ & $\begin{array}{l}0.51 * * * \\
(0.013)\end{array}$ & $\begin{array}{l}0.52 * * * \\
(0.017)\end{array}$ & $\begin{array}{l}0.00 * * * \\
(0.000)\end{array}$ & $\begin{array}{l}0.52 * * * \\
(0.016)\end{array}$ \\
\hline L.TRADE & $\begin{array}{l}-20.27 * * * \\
(0.231)\end{array}$ & $\begin{array}{l}-20.26^{* * *} \\
(0.238)\end{array}$ & $\begin{array}{l}-20.24 * * * \\
(0.253)\end{array}$ & $\begin{array}{l}-20.27 * * * \\
(0.231)\end{array}$ & $\begin{array}{l}-21.11 * * * \\
(0.290)\end{array}$ & $\begin{array}{l}-0.00^{* * * *} \\
(0.000)\end{array}$ & $\begin{array}{l}-19.83^{* * *} \\
(0.490)\end{array}$ \\
\hline L.FDI & $\begin{array}{l}0.39 \\
(0.939)\end{array}$ & $\begin{array}{l}0.31 \\
(0.985)\end{array}$ & $\begin{array}{l}0.39 \\
(0.958)\end{array}$ & $\begin{array}{l}0.39 \\
(0.939)\end{array}$ & $\begin{array}{l}-0.37 \\
(1.242)\end{array}$ & $\begin{array}{l}0.00 \\
(0.000)\end{array}$ & $\begin{array}{l}1.21 \\
(1.003)\end{array}$ \\
\hline L.CAP & $\begin{array}{l}-0.00 * * * \\
(0.000)\end{array}$ & $\begin{array}{l}-0.00 * * * \\
(0.000)\end{array}$ & $\begin{array}{l}-0.00^{* * * *} \\
(0.000)\end{array}$ & $\begin{array}{l}-0.00^{* * * *} \\
(0.000)\end{array}$ & $\begin{array}{l}-0.00^{* * * *} \\
(0.000)\end{array}$ & $\begin{array}{l}-0.00^{* * * *} \\
(0.000)\end{array}$ & $\begin{array}{l}-0.00^{* * * *} \\
(0.000)\end{array}$ \\
\hline L.INDUS & $\begin{array}{l}65.91 * * * \\
(6.845)\end{array}$ & $\begin{array}{l}61.80 * * * \\
(6.937)\end{array}$ & $\begin{array}{l}63.00^{* * * *} \\
(6.721)\end{array}$ & $\begin{array}{l}65.91 * * * \\
(6.845)\end{array}$ & $\begin{array}{l}51.15^{* * * *} \\
(6.471)\end{array}$ & $\begin{array}{l}0.01 * * * \\
(0.001)\end{array}$ & $\begin{array}{l}53.04 * * * \\
(6.323)\end{array}$ \\
\hline L.GE & $\begin{array}{l}0.66 \\
(1.111)\end{array}$ & $\begin{array}{l}-0.28 \\
(0.969)\end{array}$ & $\begin{array}{l}-0.04 \\
(1.123)\end{array}$ & $\begin{array}{l}0.66 \\
(1.111)\end{array}$ & $\begin{array}{l}2.52 * \\
(1.328)\end{array}$ & $\begin{array}{l}0.00 \\
(0.000)\end{array}$ & $\begin{array}{l}-5.94 * * * \\
(1.352)\end{array}$ \\
\hline Observations & 192 & 192 & 192 & 192 & 104 & 168 & 168 \\
\hline$R$-squared & 0.796 & 0.794 & 0.794 & 0.796 & 0.822 & 0.825 & 0.821 \\
\hline $\begin{array}{r}\text { Number of } \\
\text { countries }\end{array}$ & 24 & 24 & 24 & 24 & 24 & 24 & 24 \\
\hline
\end{tabular}

Standard errors in parentheses

$* * * p<0.01, * * p<0.05, * p<0.1$

DT is the digital transformation that refers to each variable used to capture digitalization in the business sector (including e-Commerce sales (eCOM_Sales), e-Commerce turnover (eCOM_Turn), e-Commerce web sales $\left(e C O M \_W e b\right)$, and customer relation management (CRM) usage $\left(e B U S S_{-} C R P\right)$ and cloud usage $\left.\left(e B U S S_{-} C l o u d\right)\right)$ and in the public sector (including business mobility $\left(e G O V_{-} B M\right)$ and key enablers $\left(e G O V_{-}\right.$ $K E)$ ). The notation "L." before variables means that these explanatory variables are lagged by one period

such as big data, the cloud is extremely important to secure the energy system, especially the availability of energy. By contrast, the empirical evidence suggests that digital public services are detrimental for the availability, acceptability, and develop-ability of energy systems but beneficial for sustainable development. To confirm our findings, the FGLS model is also applied. We report the results in Tables 9, 10, 11, 12, and 13 in Appendix. The results still hold the same, suggesting that our findings are robust and reliable.

\section{Further discussions on the role of digital public services}

Until now, our findings demonstrate that digital public services adversely affect the availability, acceptability, and develop-ability of ES. However, we argue that the digital public services may help to promote the ES if the digital transformation in the public sector reaches a certain level. In this section, we, therefore, examine whether there is a nonlinear effect of digital activities coming from the public service sector on the ES. We use $e G O V$ to denote digital activities in the public sector. According to the PCSE estimations in Table 8, there is a nonlinear relationship between digital public service and ES1, ES2, ES4, ES5, ES6, and ES7. These relationships reveal the different directions of digital public service's nonlinear influence on various dimensions of the ES. Regarding the availability of energy security, both the ES1 and ES2 decrease when the scale of digital public service reaches a certain point. It implies that the digital public services may not be good for the availability dimension of the ES when they cause both the gap between energy demand and supply, and energy supply capacity to decrease. Regarding the acceptability and develop-ability of the ES, the application of digital transformation initially leads to an increase in primary energy consumption and level of intensity of primary energy (ES4 and ES5). However, when increasing the scale of digitization to a certain extent, the government becomes to be less dependent on these factors. The nonlinear relationship between digital public services with ES1, ES2, ES4, and ES5 is in the shape of the invert- $U$ curve. We use predictive margins 
Table 8 Nonlinear digital public service on energy security

\begin{tabular}{|c|c|c|c|c|c|c|c|c|}
\hline & (1) & (2) & (3) & (4) & (5) & (6) & (7) & (8) \\
\hline & \multicolumn{8}{|c|}{ PCSE estimates } \\
\hline Variables & ES1 & $\mathrm{ES} 2$ & ES3 & ES4 & ES5 & ES6 & ES7 & ES8 \\
\hline L.eGOV & $\begin{array}{l}0.00 \\
(0.001)\end{array}$ & $\begin{array}{l}0.09 * * * \\
(0.026)\end{array}$ & $\begin{array}{l}0.00 \\
(0.002)\end{array}$ & $\begin{array}{l}0.01 * * * \\
(0.003)\end{array}$ & $\begin{array}{l}0.00^{* * * *} \\
(0.000)\end{array}$ & $\begin{array}{l}-0.00 \\
(0.001)\end{array}$ & $\begin{array}{l}-0.00 \\
(0.000)\end{array}$ & $\begin{array}{l}0.00 * \\
(0.001)\end{array}$ \\
\hline L.eGOV ${ }^{2}$ & $\begin{array}{l}-0.00 * * * \\
(0.000)\end{array}$ & $\begin{array}{l}-0.00 * * * \\
(0.000)\end{array}$ & $\begin{array}{l}-0.00 \\
(0.000)\end{array}$ & $\begin{array}{l}-0.00 * * * \\
(0.000)\end{array}$ & $\begin{array}{l}-0.00 * * \\
(0.000)\end{array}$ & $\begin{array}{l}0.00 \\
(0.000)\end{array}$ & $\begin{array}{l}0.00 * * \\
(0.000)\end{array}$ & $\begin{array}{l}-0.00 \\
(0.000)\end{array}$ \\
\hline L.GDP & $\begin{array}{l}0.01 * * * \\
(0.000)\end{array}$ & $\begin{array}{l}0.13^{* * * *} \\
(0.005)\end{array}$ & $\begin{array}{l}0.00^{* * * *} \\
(0.000)\end{array}$ & $\begin{array}{l}-0.00^{* * * *} \\
(0.001)\end{array}$ & $\begin{array}{l}0.00 * * * \\
(0.000)\end{array}$ & $\begin{array}{l}-0.00^{* * * *} \\
(0.000)\end{array}$ & $\begin{array}{l}-0.00 \text { *** } \\
(0.000)\end{array}$ & $\begin{array}{l}0.01 * * * \\
(0.000)\end{array}$ \\
\hline L.TRADE & $\begin{array}{l}-0.12^{* * * *} \\
(0.011)\end{array}$ & $\begin{array}{l}-1.33 \text { *** } \\
(0.202)\end{array}$ & $\begin{array}{l}-0.23 * * * \\
(0.008)\end{array}$ & $\begin{array}{l}-0.15^{* * *} \\
(0.032)\end{array}$ & $\begin{array}{l}-0.00 \text { *** } \\
(0.000)\end{array}$ & $\begin{array}{l}0.08 * * * \\
(0.007)\end{array}$ & $\begin{array}{l}0.00 \text { *** } \\
(0.000)\end{array}$ & $\begin{array}{l}-0.22 * * * \\
(0.006)\end{array}$ \\
\hline L.FDI & $\begin{array}{l}-0.02 \\
(0.027)\end{array}$ & $\begin{array}{l}-0.97 * * \\
(0.422)\end{array}$ & $\begin{array}{l}-0.01 \\
(0.022)\end{array}$ & $\begin{array}{l}-0.12^{* *} \\
(0.053)\end{array}$ & $\begin{array}{l}-0.00 \\
(0.000)\end{array}$ & $\begin{array}{l}-0.00 \\
(0.008)\end{array}$ & $\begin{array}{l}-0.00^{* * * *} \\
(0.000)\end{array}$ & $\begin{array}{c}-0.03 \\
(0.023)\end{array}$ \\
\hline L.CAP & $\begin{array}{l}-0.00^{* * * *} \\
(0.000)\end{array}$ & $\begin{array}{l}-0.00 \text { *** } \\
(0.000)\end{array}$ & $\begin{array}{l}-0.00^{* * *} \\
(0.000)\end{array}$ & $\begin{array}{l}-0.00 \text { *** } \\
(0.000)\end{array}$ & $\begin{array}{l}-0.00 \text { *** } \\
(0.000)\end{array}$ & $\begin{array}{l}-0.00^{* * * *} \\
(0.000)\end{array}$ & $\begin{array}{l}-0.00^{* * * *} \\
(0.000)\end{array}$ & $\begin{array}{l}-0.00 \text { *** } \\
(0.000)\end{array}$ \\
\hline L.INDUS & $\begin{array}{l}-1.63^{* * *} \\
(0.120)\end{array}$ & $\begin{array}{l}-6.42 * * * \\
(1.113)\end{array}$ & $\begin{array}{l}0.61 * * * \\
(0.075)\end{array}$ & $\begin{array}{l}-1.12 \text { *** } \\
(0.273)\end{array}$ & $\begin{array}{l}-0.00 \\
(0.000)\end{array}$ & $\begin{array}{l}0.33^{* * * *} \\
(0.056)\end{array}$ & $\begin{array}{l}-0.00^{* * * *} \\
(0.001)\end{array}$ & $\begin{array}{l}0.35^{* * *} \\
(0.060)\end{array}$ \\
\hline L.GE & $\begin{array}{l}0.09 * * * \\
(0.018)\end{array}$ & $\begin{array}{l}0.11 \\
(0.253)\end{array}$ & $\begin{array}{l}0.04 * * * \\
(0.011)\end{array}$ & $\begin{array}{l}0.17 * * * \\
(0.060)\end{array}$ & $\begin{array}{l}0.00 \\
(0.000)\end{array}$ & $\begin{array}{l}-0.06^{* * *} \\
(0.015)\end{array}$ & $\begin{array}{l}0.00 \\
(0.000)\end{array}$ & $\begin{array}{l}-0.05 * * * \\
(0.012)\end{array}$ \\
\hline Observations & 112 & 112 & 168 & 112 & 168 & 168 & 168 & 168 \\
\hline$R$-squared & 0.862 & 0.572 & 0.590 & 0.155 & 0.364 & 0.599 & 0.547 & 0.686 \\
\hline \multirow[t]{2}{*}{ Number of countries } & 28 & 28 & 28 & 28 & 28 & 28 & 28 & 28 \\
\hline & \multicolumn{8}{|c|}{ FGLS estimate } \\
\hline Variables & ES1 & ES2 & ES3 & ES4 & ES5 & ES6 & ES7 & ES8 \\
\hline L.eGOV & $\begin{array}{l}0.00 \\
(0.002)\end{array}$ & $\begin{array}{l}0.09 * * \\
(0.044)\end{array}$ & $\begin{array}{l}0.00 \\
(0.002)\end{array}$ & $\begin{array}{l}0.01 \\
(0.010)\end{array}$ & $\begin{array}{l}0.00 * \\
(0.000)\end{array}$ & $\begin{array}{l}-0.00 \\
(0.001)\end{array}$ & $\begin{array}{l}-0.00 \\
(0.000)\end{array}$ & $\begin{array}{l}0.00 * \\
(0.000)\end{array}$ \\
\hline L.eGOV ${ }^{2}$ & $\begin{array}{l}-0.00 * * \\
(0.000)\end{array}$ & $\begin{array}{l}-0.00 * \\
(0.000)\end{array}$ & $\begin{array}{c}-0.00 \\
(0.000)\end{array}$ & $\begin{array}{l}-0.00 \\
(0.000)\end{array}$ & $\begin{array}{c}-0.00 \\
(0.000)\end{array}$ & $\begin{array}{l}0.00 \\
(0.000)\end{array}$ & $\begin{array}{l}0.00 * * \\
(0.000)\end{array}$ & $\begin{array}{l}-0.00 \\
(0.000)\end{array}$ \\
\hline L.GDP & $\begin{array}{l}0.01 * * * \\
(0.001)\end{array}$ & $\begin{array}{l}0.13^{* * *} \\
(0.018)\end{array}$ & $\begin{array}{l}0.00^{* * * *} \\
(0.001)\end{array}$ & $\begin{array}{l}-0.00 \\
(0.004)\end{array}$ & $\begin{array}{l}0.00 \text { **** } \\
(0.000)\end{array}$ & $\begin{array}{l}-0.00^{* * * *} \\
(0.001)\end{array}$ & $\begin{array}{l}-0.00^{* * * *} \\
(0.000)\end{array}$ & $\begin{array}{l}0.00^{* * * *} \\
(0.000)\end{array}$ \\
\hline L.TRADE & $\begin{array}{l}-0.12 \text { *** } \\
(0.026)\end{array}$ & $\begin{array}{l}-1.33 * * \\
(0.563)\end{array}$ & $\begin{array}{l}-0.23^{* * *} \\
(0.019)\end{array}$ & $\begin{array}{l}-0.15 \\
(0.124)\end{array}$ & $\begin{array}{l}-0.00^{* *} \\
(0.000)\end{array}$ & $\begin{array}{l}0.08 * * * \\
(0.017)\end{array}$ & $\begin{array}{l}0.00 * * * \\
(0.000)\end{array}$ & $\begin{array}{l}-0.00 * * * \\
(0.000)\end{array}$ \\
\hline L.FDI & $\begin{array}{l}-0.02 \\
(0.042)\end{array}$ & $\begin{array}{l}-0.97 \\
(0.899)\end{array}$ & $\begin{array}{l}-0.01 \\
(0.027)\end{array}$ & $\begin{array}{l}-0.12 \\
(0.198)\end{array}$ & $\begin{array}{l}-0.00 \\
(0.000)\end{array}$ & $\begin{array}{c}-0.00 \\
(0.024)\end{array}$ & $\begin{array}{l}-0.00 * * \\
(0.000)\end{array}$ & $\begin{array}{l}-0.00 \\
(0.000)\end{array}$ \\
\hline L.CAP & $\begin{array}{l}-0.00 \\
(0.000)\end{array}$ & $\begin{array}{l}-0.00 \text { *** } \\
(0.000)\end{array}$ & $\begin{array}{l}-0.00 \text { *** } \\
(0.000)\end{array}$ & $\begin{array}{l}-0.00 \text { *** } \\
(0.000)\end{array}$ & $\begin{array}{l}-0.00 \text { *** } \\
(0.000)\end{array}$ & $\begin{array}{l}-0.00 \\
(0.000)\end{array}$ & $\begin{array}{l}-0.00^{* * * *} \\
(0.000)\end{array}$ & $\begin{array}{l}-0.00 * * * \\
(0.000)\end{array}$ \\
\hline L.INDUS & $\begin{array}{l}-1.63^{* * *} \\
(0.241)\end{array}$ & $\begin{array}{l}-6.42 \\
(5.181)\end{array}$ & $\begin{array}{l}0.61 * * * \\
(0.181)\end{array}$ & $\begin{array}{l}-1.12 \\
(1.139)\end{array}$ & $\begin{array}{l}-0.00 \\
(0.000)\end{array}$ & $\begin{array}{l}0.33 * * \\
(0.160)\end{array}$ & $\begin{array}{l}-0.00^{* *} \\
(0.002)\end{array}$ & $\begin{array}{l}0.00 \\
(0.000)\end{array}$ \\
\hline L.GE & $\begin{array}{l}0.09 * * \\
(0.037)\end{array}$ & $\begin{array}{l}0.11 \\
(0.795)\end{array}$ & $\begin{array}{l}0.04 \\
(0.029)\end{array}$ & $\begin{array}{l}0.17 \\
(0.175)\end{array}$ & $\begin{array}{l}0.00 \\
(0.000)\end{array}$ & $\begin{array}{l}-0.06^{* *} \\
(0.025)\end{array}$ & $\begin{array}{l}0.00 \\
(0.000)\end{array}$ & $\begin{array}{c}-0.00 \\
(0.000)\end{array}$ \\
\hline Observations & 112 & 112 & 168 & 112 & 168 & 168 & 168 & 168 \\
\hline Number of countries & 28 & 28 & 28 & 28 & 28 & 28 & 28 & 28 \\
\hline
\end{tabular}

Standard errors in parentheses

$* * * p<0.01, * * p<0.05, * p<0.1$

DT is the digital transformation that refers to digitalization in the public sector. The notation "L." before variables means that these explanatory variables are lagged by one period

analysis to display our conclusion in Fig. 1. Regarding sustainability, we still indicate that digital public services are beneficial for sustainable development when they encourage to consume more the renewable energy. The findings of this discussion provide empirical evidence to support our belief that digital public services play a critical role in securing the energy system, especially acceptability, develop-ability, and sustainability. 


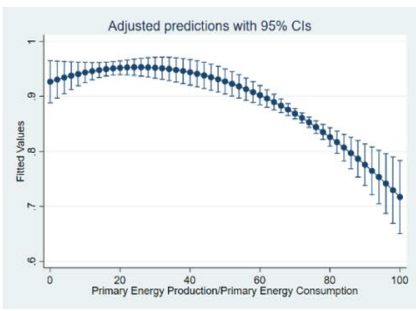

a)ES1

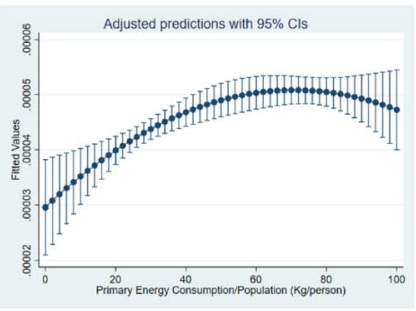

d)ES5

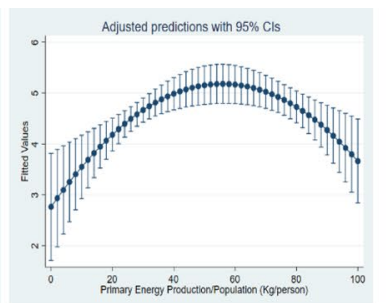

b)ES2

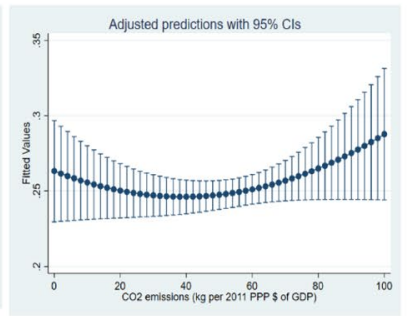

f)ES6

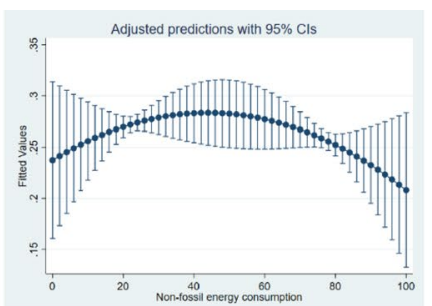

c)ES3

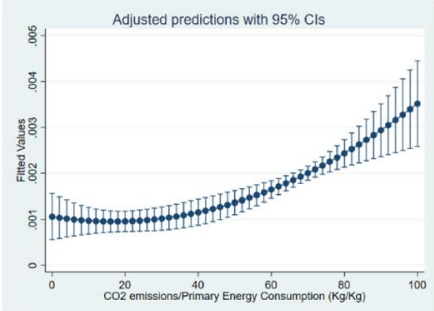

e)ES7

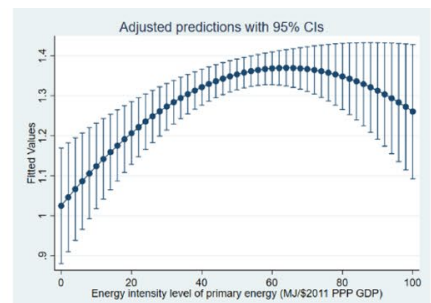

d)ES4

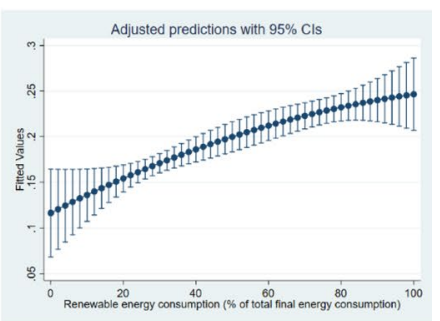

f)ES8

Fig. 1 Predictive margin of digital public services on energy security

\section{Conclusions}

As the essential base for human beings and economic growth, energy, and its security are among the critical issues in the sustainable development agenda of any country. We are the first to empirically analyze the impact of digital business and digital public service on energy security. Using an international sample of 24 European countries during the 2011-2019 period, we reveal interesting findings. First, we demonstrate that the application of digitalization by enterprises has a beneficial effect on the acceptability and developability of ES by reducing the intensity of primary energy, primary energy consumption, and $\mathrm{CO}_{2}$ emissions. The use of modern digital technology such as big data, cloud computing is extremely important to secure the energy system, especially for the availability of energy. By contrast, empirical evidence suggests that the development of digital public services is detrimental to the availability, acceptability, and develop-ability of energy systems but beneficial for sustainable development. Second, the study examines the nonlinear influence of digital public services on ES. We find that when the process of integrating digitization into the public sectors reaches a certain extent, there will be an increase in energy efficiency, as demonstrated by a reduction in the level of intensity of primary energy and primary energy consumption. Third, referring to the short-term and long-term impact of e-government on ES, we reaffirm the efficiency in energy use when the government adopts digitalization.

This paper plays a critical role in contributing to the extant literature regarding the determinants of energy security. We emphasize the role of the digital transformation process that is adopted in the business sector and public sector. Previous studies, such as Faisal et al. (2018), Ferro (2011), Haini (2019) Owusu-Agyei et al. (2020), Tamazian et al. (2009), and Salahuddin et al. (2015) have simply assessed the effects of the internet use, the prevalence of phones or electronic devices, or some technological improvement on the specific aspect of energy security. Other papers like Dogan and Aslan (2017), Gokmenoglu and Eren (2019), Khan and Hou (2021a, b), Khan et al. (2021c), or Zakari and Khan (2021) concentrate on the influences of energy security on the various dimensions of economic development. The common point of these studies is that they focus on only one specific aspect of energy security. By pointing out the importance of digital transformation activities taking place in the different sectors on the variety of energy aspects of energy security, including availability, acceptability, develop-ability, and sustainability, our paper provides a comprehensive analysis of the nexus of digitalization and energy security. The contribution of this paper is to construct a theoretical and empirical link between digitalization and energy security. The second novelty of this paper is to demonstrate the differences between digital business and digital public services by pointing out the existence of a nonlinear relationship between digitalization in the public sector and energy security. In other words, digital public services only enhance energy security if the digital transformation in the public sector reaches a certain level. By using the modern econometric techniques that permit us to control a variety of technical issues for the data with the presence of cross-sectional dependence, we provide reliable and robust evidence for our conclusions. 
On the policy front, our study and many previous papers emphasize the importance of energy security on the development of the economy. Therefore, policymakers should design a policy that promotes a sustained lifestyle from the consumption and production perspective, ecological awareness, clean and environmental innovations. The study of Yang and Khan (2021) provides supporting evidence for our policy proposal. As we have analyzed in the long run, scaling up the digital transformation process has the effect of reducing the scale of $\mathrm{CO}_{2}$ emissions as well as increasing energy efficiency. In addition, the linear effect also shows that the application of digitization in businesses also has positive effects on ES, such as promoting developability, reducing the level of intensity of primary energy. To secure the availability of energy, governments should encourage enterprises to integrate modern digital technologies, which can help promote energy production or reduce energy intensity. Support policies, including economic support (e.g., financial supports, tax reductions, and some preferential policies), technical support, and legal support in connecting foreign firms, or transferring technologies are necessary to promote digitalization in the business sectors. Energy investment, especially cleaner energy infrastructure is crucial for environmental sustainability (Lyu et al. 2021). As the same proposal raised by Zahoo et al. (2021), we also recommend that the government should play a vital role in removing the barriers to prevent people from using cleaner or renewable energy and to ensure energy security, resolving disincentives, subsidies, and addressing regulatory and market rigidities, which may undesirably influence the use of clean and renewable energy investment. Notably, we also recommend that energy security requires a persistent and continuous integration of digitalization into the public sectors.
The findings of this study could be interpreted in light of limitations. In this paper, we only utilized the archival data accumulated only for the European Union area in the short period (2011-2019). Although energy security has been accelerated in this area, it is vital to consider the role of digitalization in promoting the security of energy in developing areas as well. More research will follow with the incoming flow of more sophisticated and updated data. In particular, we would want to delve deeper into each separate component of the digitalization process to find out more about their impacts on energy security and sustainable development. Furthermore, this paper incorporates and stresses the environmental perspectives using the various dimensions of energy security, but future research could also include the socio-economic and political aspects of European countries.

\section{Appendix}

Table 9 Countries in the sample

\begin{tabular}{lll}
\hline EU countries & & \\
\hline Austria & Hungary & Portugal \\
Belgium & Iceland & Slovak Republic \\
Bulgaria & Ireland & Slovenia \\
Czech Republic & Italy & Sweden \\
Denmark & Lithuania & \\
Spain & Luxembourg & \\
Estonia & Latvia & \\
UK & Malta & \\
Greece & Netherlands & \\
Croatia & Poland & \\
\hline
\end{tabular}




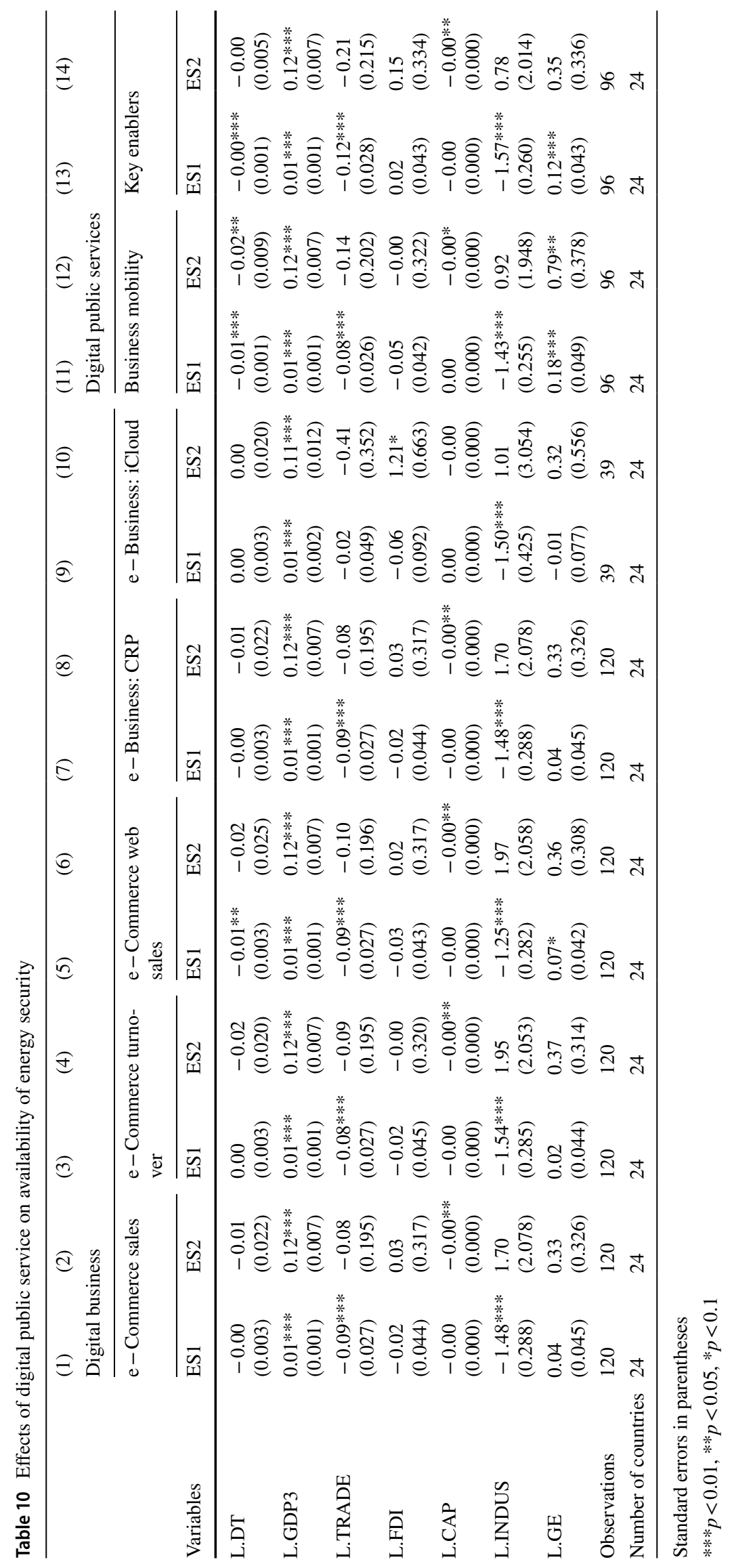




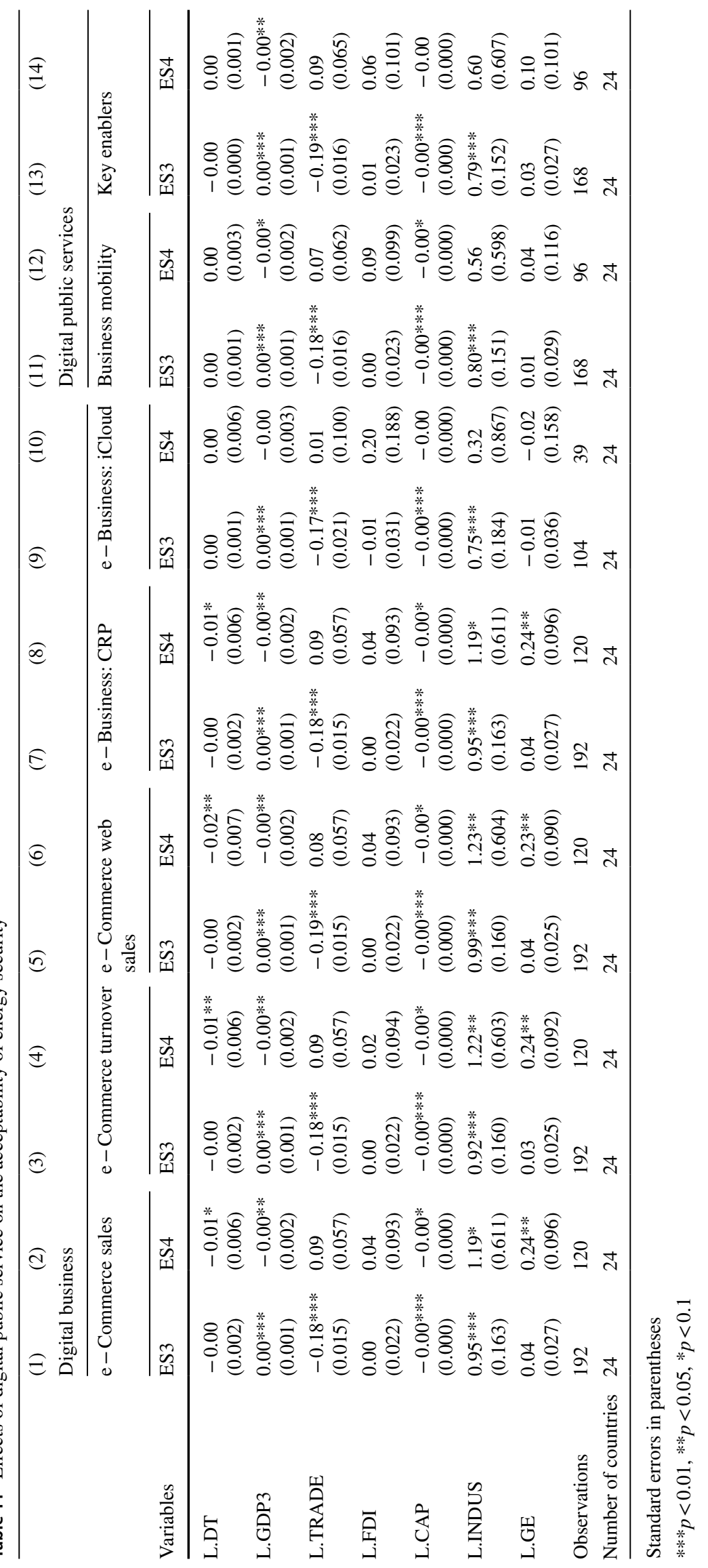




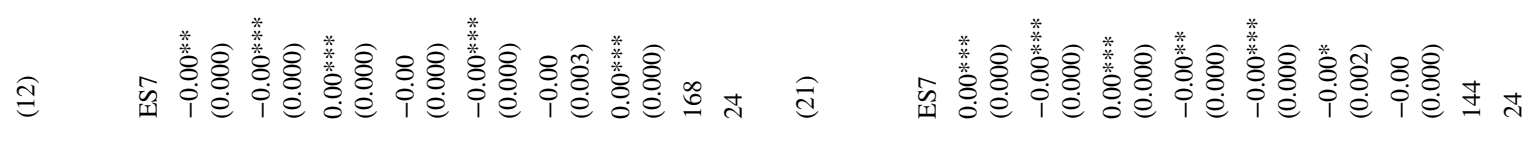

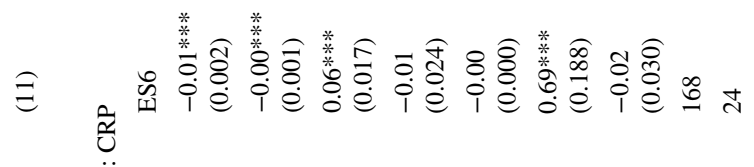

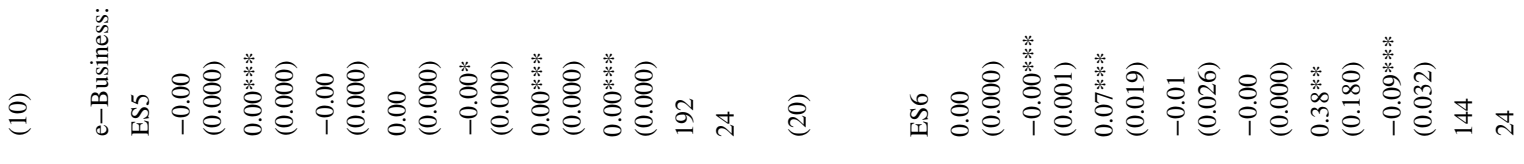

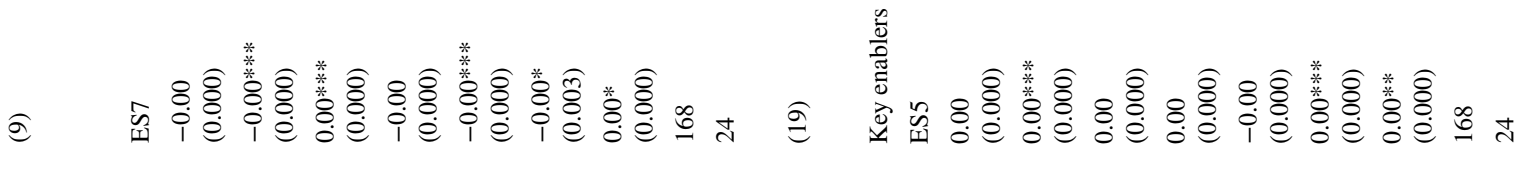

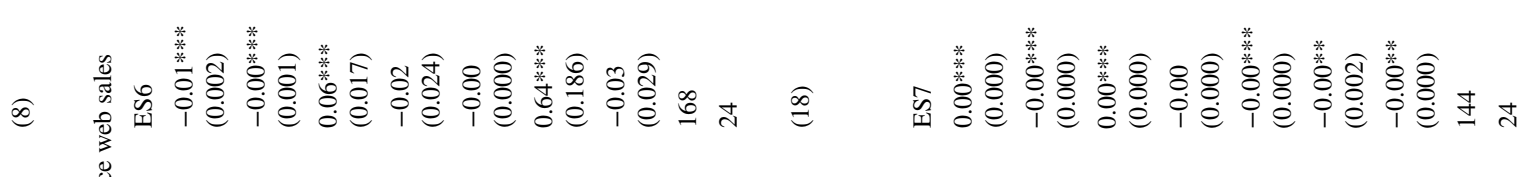

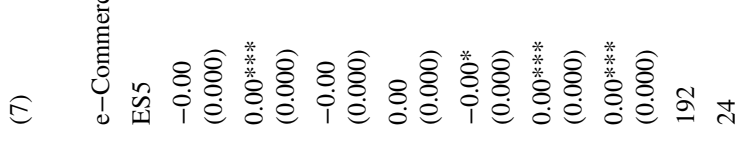

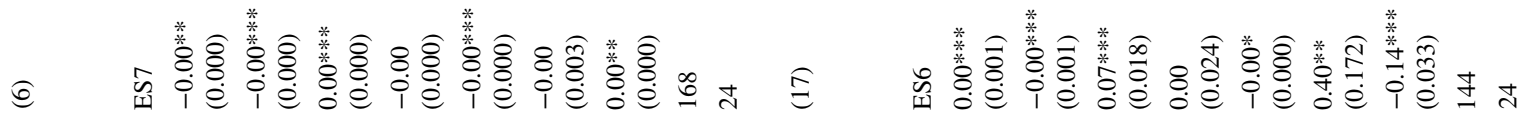

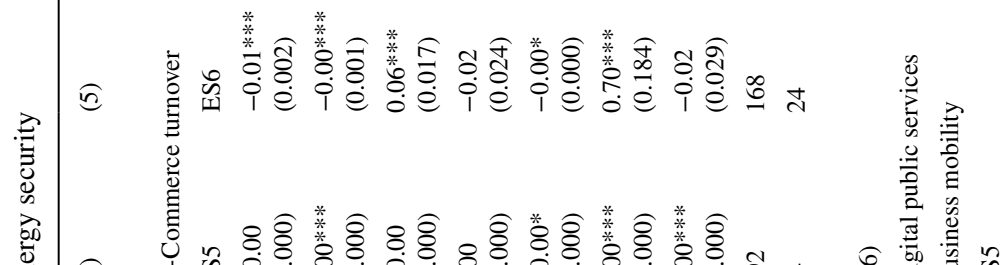

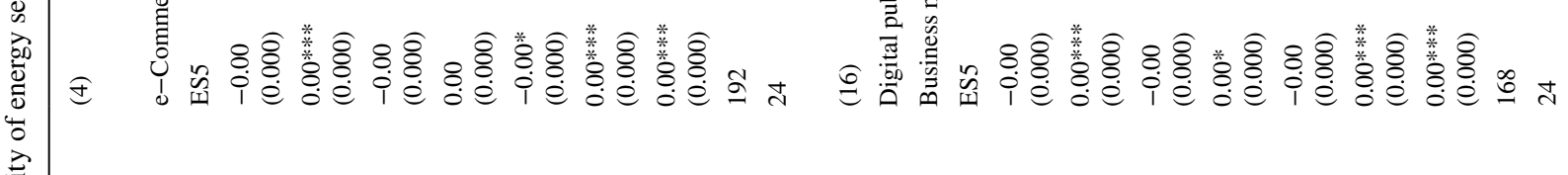

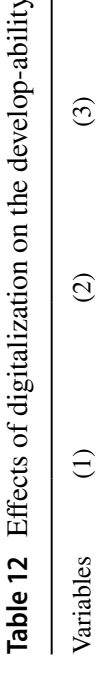

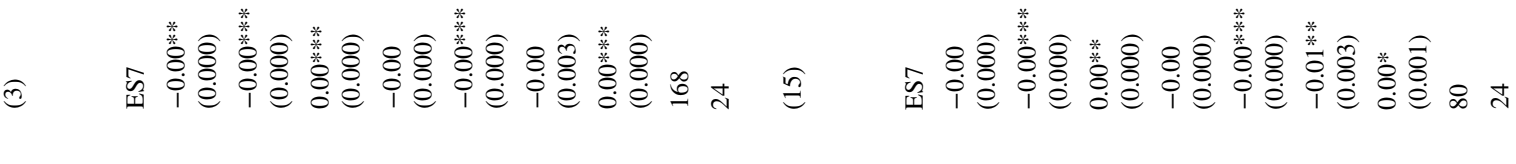

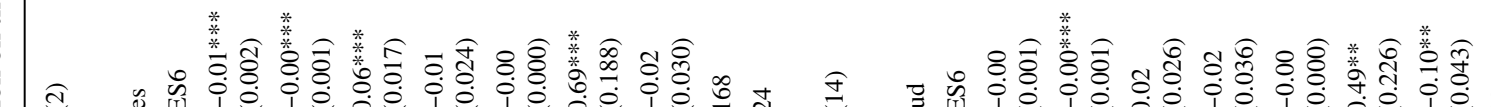

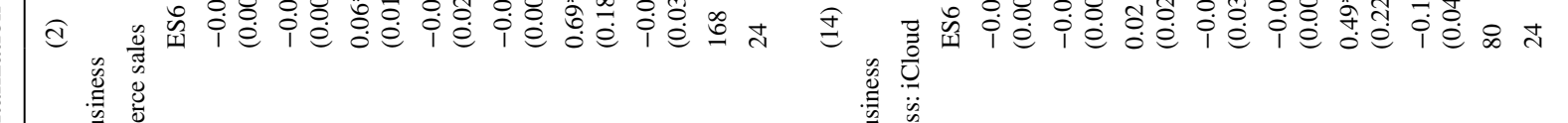

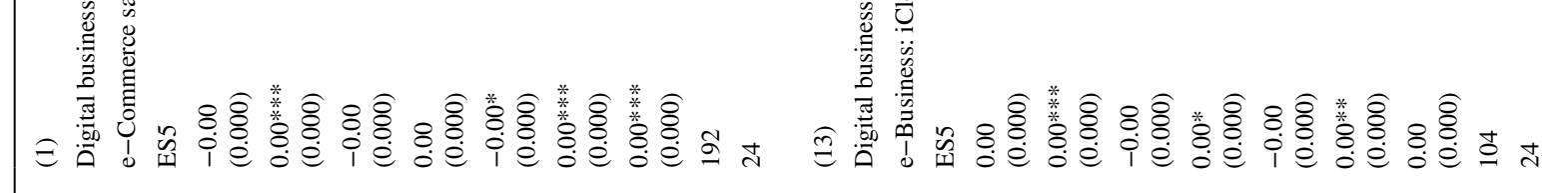

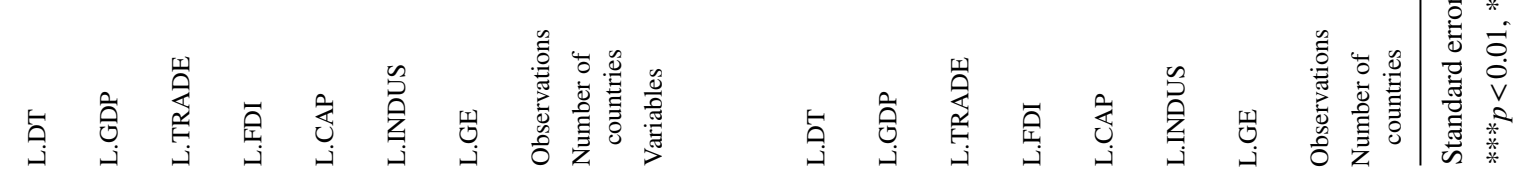




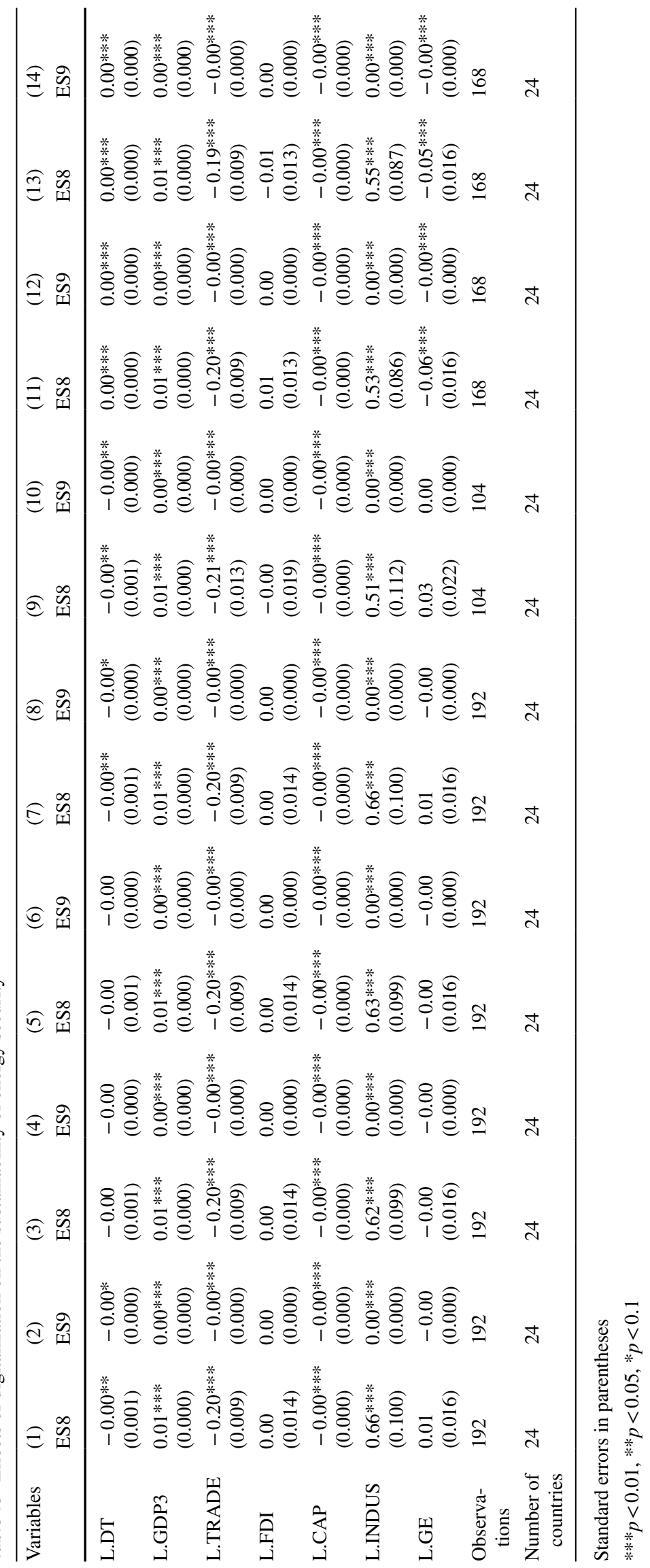


Author contribution Le Thanh Ha was equally contributed to all stages of preparing, drafting, writing, and revising this review article. All authors listed have made a substantial, direct, and intellectual contribution to the work during different preparation stages. All authors read, revised, and approved the final version of this manuscript.

Funding This paper was supported by National Economics University.

Data availability Data available on request due to privacy/ethical restrictions.

\section{Declarations}

Conflict of interest The author declares no competing interests.

\section{References}

Ahn MJ, Bretschneider S (2011) Politics of e-government: E-government and the political control of bureaucracy. Public Adm Rev 71(3):414-424

Ahmedov I (2020) The impact of digital economy on international trade. Eur J Bus Manag Res 5(4). https://doi.org/10.24018/ejbmr. 2020.5.4.389

Airehrour D, Gutiérrez J, Ray SK (2016) Greening and optimizing energy consumption of sensor nodes in the Internet of things through energy harvesting: challenges and approaches. International Conference on Information Resources Management (ConfIRM 2016), Cape Town, South Africa

APERC (2007) Quest for energy security in the 21st century: resources and constraints. Asia Pacific Energy Research Centre, Tokyo, Japan

Bakhsh K, Rose S, Ali MF, Ahmad N, Shahbaz M (2017) Economic growth, $\mathrm{CO} 2$ emissions, renewable waste and FDI relation in Pakistan: new evidences from 3SLS. J Environ Manage 196:627632. https://doi.org/10.1016/j.jenvman.2017.03.029

Basu S, Fernald J (2007) Information and communications technology as a general-purpose technology: evidence from US industry data. German Econ Rev 8(2):146-173. https://doi.org/10.1111/j. 1468-0475.2007.00402.x

Beck N, Katz JN (1995) What to do (and not to do) with time-series cross-section data. Am Polit Sci Rev 89(3):634-647. https://doi. org $/ 10.2307 / 2082979$

Berkhout F, Hertin J (2001) Impacts of information and communication technologies on environmental sustainability: speculations and evidence. Report to the OECD, Brighton

Bernstein R, Madlener R (2010) Impact of disaggregated ICT capital on electricity intensity in European manufacturing. Appl Econ Lett 17(17):1691-1695. https://doi.org/10.1080/13504850903120717

Bertot JC, Jaeger PT, Grimes JM (2010) Using ICTs to create a culture of transparency: e-government and social media as openness and anti-corruption tools for societies. Gov Inf Q 27(3):264-271

Bhatnagar S, Singh N (2010) Assessing the impact of E-Government: a study of E-Government projects in India. Information Technologies and International Development 6(2):109-127

Bi K, Huang P, Ye H (2015) Risk identification, evaluation and response of low-carbon technological innovation under the global value chain: a case of the Chinese manufacturing industry. Technol Forecast Soc Chang 100:238-248. https://doi.org/10.1016/j. techfore.2015.07.005

Canh NP, Thanh SD (2020) Financial development and the shadow economy: a multi-dimensional analysis. Econ Anal Policy 67:3754. https://doi.org/10.1016/j.eap.2020.05.002
Canh PN, Schinckus C, Thanh SD (2021) What are the drivers of shadow economy? A further evidence of economic integration and institutional quality. J Int Trade Econ Dev 30(1):47-67. https:// doi.org/10.1080/09638199.2020.1799428

Castro C, Lopes C (2021) Digital government and sustainable development. J Knowl Econ. https://doi.org/10.1007/s13132-021-00749-2

Ceccobelli M, Gitto S, Mancuso P (2012) ICT capital and labour productivity growth: a non-parametric analysis of 14 OECD countries. Telecommun Policy 36(4):282-292. https://doi.org/10. 1016/j.telpol.2011.12.012

Collard F, Fève P, Portier F (2005) Electricity consumption and ICT in the French service sector. Energy Econ 27(3):541-550. https:// doi.org/10.1016/j.eneco.2004.12.002

Dogan E, Aslan A (2017) Exploring the relationship among $\mathrm{CO}_{2}$ emissions, real GDP, energy consumption and tourism in the EU and candidate countries: evidence from panel models robust to heterogeneity and cross-sectional dependence. Renew Sustain Energy Reviewa 77(4):239-245. https://doi.org/10.1016/j.rser.2017.03. 111

Dost F, Maier E (2018) E-Commerce effects on energy consumption: a multi-year ecosystem-level assessment. J Ind Ecol 22(4):799-812. https://doi.org/10.1111/jiec.12639

Dunnewijk T, Hultén S (2007) A brief history of mobile communication in Europe. Telematics Inform 24(3):164-179. https://doi.org/ 10.1016/j.tele.2007.01.013

European Commission (1999) The EU's eco-industry's export potential. Final report to DGXI of the European Commission

Farhadi M, Ismail R, Fooladi M (2012) Information and communication technology use and economic growth. PLoS One 7(11):e48903. https://doi.org/10.1371/journal.pone.0048903

Franco C, Marin G (2015) The effect of within-sector, upstream and downstream environmental taxes on innovation and productivity. Environ Resource Econ 66(2):261-291. https://doi.org/10.1007/ s10640-015-9948-3

Faisal F, Tursoy T, Berk N (2018) Linear and non-linear impact of Internet usage and financial deepening on electricity consumption for Turkey: empirical evidence from asymmetric causality. Environ Sci Pollut Res 25(12):11536-11555. https://doi.org/10. 1007/s11356-018-1341-7

Fang D, Shi S, Yu Q (2018) Evaluation of sustainable energy security and an empirical analysis of China. Sustainability 10(5):1685. https://doi.org/10.3390/su10051685

Ferro E (2011) Signaling and technological marketing tools for exporters. World Bank

Font Vivanco D, Kemp R, van der Voet E, Heijungs R (2014) Using LCA-based decomposition analysis to study the multidimensional contribution of technological innovation to environmental pressures. J Ind Ecol 18(3):380-392. https://doi.org/10.1111/jiec. 12118

Gala P, Camargo J, Magacho G, Rocha I (2018) Sophisticated jobs matter for economic complexity: an empirical analysis based on input-output matrices and employment data. Struct Chang Econ Dyn 45:1-8. https://doi.org/10.1016/j.strueco.2017.11.005

Galeotti M, Manera M, Lanza A (2008) On the robustness of robustness checks of the environmental Kuznets curve hypothesis. Environ Resource Econ 42(4):551-574. https://doi.org/10.1007/ s10640-008-9224-x

Gokmenoglu KK, Eren BM (2020) The role of international tourism on energy consumption: empirical evidence from Turkey. Current Issues in Tourism 23(9):1059-1065. https://doi.org/10.1080/ 13683500.2019.1574723

Haider Zaidi SA, Zafar MW, Shahbaz M, Hou F (2019) Dynamic linkages between globalization, financial development and carbon emissions: evidence from Asia Pacific Economic Cooperation countries. J Clean Prod 228:533-543. https://doi.org/10.1016/j. jclepro.2019.04.210 
Haigh N, Griffiths A (2008) E-government and environmental sustainability: results from three Australian cases. Electron Gov Int J 5(1):45. https://doi.org/10.1504/EG.2008.016127

Haini H (2019) Internet penetration, human capital and economic growth in the ASEAN economies: evidence from a translog production function. Appl Econ Lett 26(21):1774-1778. https://doi. org/10.1080/13504851.2019.1597250

Heeks R (2001) Understanding eGovernance for Development. Institute for Development Policy and Management, Manchester, UK

Heeks R (1999) The tyranny of participation in information systems: Learning from development projects. Institute for Development Policy and Management. University of Manchester. http://idpm. man.ac.uk/idpm/di_wp4.htm

Huber JD, Martinez-Gallardo C (2008) Replacing cabinet ministers: Patterns of ministerial stability in parliamentary democracies. The American Political Science Review 102(2):169-180

Huberty M, Gao H, Mandell J, Zysman J (2011) Shaping the green growth economy: a review of the public debate and the prospects for green growth. The Berkeley Roundtable on the International Economy

Im KS, Pesaran MH, Shin Y (2003) Testing for unit roots in heterogeneous panels. J Econ 115(1):53-74. https://doi.org/10.1016/ S0304-4076(03)00092-7

International Trade Centre (2001) The environmental services business: big and growing. Int Trade Forum 2:6-9

Ishida $\mathrm{H}$ (2015) The effect of ICT development on economic growth and energy consumption in Japan. Telematics Inform 32(1):79-88. https://doi.org/10.1016/j.tele.2014.04.003

Jennings ET Jr, Ewalt JAG (1998) Interorganizational coordination, administrative consolidation, and policy performance. Public Adm Rev 58(5):417-428

Kemp-Benedict E (2014) Shifting to a green economy: lock-in, path dependence, and policy options (p. 16, Rep.). Stockholm Environment Institute

Kennett M, Steenblik R (2005) Environmental goods and services: a synthesis of country studies. OECD Publishing, vol. 3

Khan I, Hou F (2021a) The dynamic links among energy consumption, tourism growth, and the ecological footprint: the role of environmental quality in 38 IEA countries. Environ Sci Pollut Res 28:5049-5062

Khan I, Hou F (2021b) Does multilateral environmental diplomacy improve environmental quality? The case of the United States. Environ Sci Pollut Res 28:23310-23322

Khan I, Hou F (2021c) The impacts of socio-economic and environmental sustainability on $\mathrm{CO}_{2}$ emissions: a novel framework for thirty IEA countries. Social Indicators Research, 3/2021

Khan I, Hou F, Le HP (2021a) The impact of natural resources, energy consumption, and population growth on environmental quality: Fresh evidence from the United States of America. Sci Total Environ $754: 142222$

Khan I, Hou F, Zakari A, Tawiah VK (2021b) The dynamic links among enery transitions, energy consumption, and sustainable economic growth: a novel framework for IEA countries. Energy 222:119935

Khan I, Hou F, Le HP, Ali SA (2021c) Do natural resources, urbanization, and value-adding manufacturing affect environmental quality? Evidence from the top ten manufacturing countries. Resource Policy 72:102109

Khan I, Hou F, Irfan M, Zakari A, Le HP (2021d) Does energy trilemma a driver of economic growth? The roles of energy use, population growth, and financial development. Renew Sustain Energy Rev 146:111157

Kumar R, Best ML (2006) Impact and Sustainability of E-Government Services in Developing Countries: Lessons Learned from Tamil Nadu, India. Inf Soc 22:1-12. https://doi.org/10.1080/0197224050 0388149
Le T-H, Nguyen CP (2019) Is energy security a driver for economic growth? Evidence from a global sample. Energy Policy 129:436451. https://doi.org/10.1016/j.enpol.2019.02.038

Le HT, Hoang DP (2021). Environ Sci Pollut Res. https://doi.org/10. 1007/s11356-021-17103-3

Lee C-C, Lee J-D (2009) Income and CO2 emissions: evidence from panel unit root and cointegration tests. Energy Policy 37(2):413423. https://doi.org/10.1016/j.enpol.2008.09.053

Lee S, Yoon B, Shin J (2016) Effects of nuclear energy on sustainable development and energy security: sodium-cooled fast reactor case. Sustainability 8(10):979. https://doi.org/10.3390/su8100979

Lehne J, Shapiro JN, Eynde OV (2018) Building connections: Political corruption and road construction in India. J Dev Econ 131:62-78

Li Q, Zhao J, Gong Y, Zhang Q (2019) Energy-efficient computation offloading and resource allocation in fog computing for internet of everything. China Community 16(3):32-41

Linde J, Karlsson M (2013) The Dictator's New Clothes: The Relationship Between E Participation and Quality of Government in Non-Democratic Regimes. Int J Pub Adm 36(4):269-281

Lyu L, Khan I, Zakari A, Bilal B (2021) A study of energy investment and environmental sustainability nexus in China: a boostrap replications analysis. Environ Sci Pollut Res. https://doi.org/10.1007/ s11356-021-16254-7

Maniatopoulos G (2005) E-government movements of organizational change: a social shaping approach. The 4th International Critical Management Studies Conference, Critique and Inclusivity: Opening the Agenda

Martínez-Zarzoso I, Maruotti A (2011) The impact of urbanization on $\mathrm{CO}_{2}$ emissions: evidence from developing countries. Ecol Econ 70(7):1344-1353. https://doi.org/10.1016/j.ecolecon.2011.02.009

Mooney JD (1947) The principles of organization. Harper, New York

Moyer JD, Hughes BB (2012) ICTs: do they contribute to increased carbon emissions? Technol Forecast Soc Chang 79(5):919-931. https://doi.org/10.1016/j.techfore.2011.12.00

OECD (2019) Trade in the digital era. Available from https://www. oecd.org/going-digital/trade-in-the-digital-era.pdf (Accessed 18th August 2021)

OECD (2020) Digital transformation in the age of COVID-19: building resilience and bridging divides. Digital Economy Outlook 2020 Supplement. Available from https://www.oecd.org/digital/digitaleconomy-outlook-covid.pdf (Accessed 18th August 2021)

Owusu-Agyei S, Okafor G, Chijoke-Mgbame AM, Ohalehi P, Hasan F (2020) Internet adoption and financial development in sub-Saharan Africa. Technol Forecast Soc Chang 161:120293. https://doi. org/10.1016/j.techfore.2020.1202

Pesaran MH (2021) General diagnostic tests for cross-sectional dependence in panels. Empir Econ 60(1):13-50. https://doi.org/10.1007/ s00181-020-01875-7

Qin J, Liu Y, Grosvenor R (2017) Data analytics for energy consumption of digital manufacturing systems using Internet of Things method. 2017 13th IEEE Conference on Automation Science and Engineering (CASE). https://doi.org/10.1109/coase.2017.8256150

Ren S, Hao Y, Xu L, Wu H, Ba N (2021) Digitalization and energy: how does internet development affect China's energy consumption? Energy Econ 98(98):1-20. https://doi.org/10.1016/j.eneco. 2021.105220

Salahuddin M, Gow J, Ozturk I (2015) Is the long-run relationship between economic growth, electricity consumption, carbon dioxide emissions and financial development in Gulf Cooperation Council Countries robust? Renew Sustain Energy Rev 51:317-326

Salahuddin M, Alam K (2016) Information and communication technology, electricity consumption and economic growth in OECD countries: a panel data analysis. Int J Electr Power Energy Syst 76:185-193. https://doi.org/10.1016/j.ijepes.2015.11.005

Salahuddin M, Gow J (2016) The effects of Internet usage, financial development and trade openness on economic growth in South 
Africa: a time series analysis. Telematics Inform 33(4):11411154. https://doi.org/10.1016/j.tele.2015.11.006

Saxena S (2017) Factors influencing perceptions on corruption in public servicedelivery via e-government platform. Foresight 19(6):628-646. https://doi.org/10.1108/FS-05-2017-0013

Shyla J (2020) Effect of digitalization on import and export. Emperor Int J Finance Manag Res 5(7):1-12

Smith A (1978) V: Lectures on jurisprudence: the glasgow edition of the works and correspondence of adam smith. Oxford University Press, UK

Sinclair-Desgagné B (2008) The environmental goods and services industry. Int Rev Environ Resour Econ 2(1):69-99

Solomon EM, van Klyton A (2020) The impact of digital technology usage on economic growth in Africa. Utilities Policy 67:101104. https://doi.org/10.1016/j.jup.2020.101104

Spiezia V (2011) Are ICT users more innovative?: an analysis of ICTenabled innovation in OECD firms. OECD J Econ Stud 2011(1). https://doi.org/10.1787/eco_studies-2011-5kg2d2hkn6vg

Sweet C, Eterovic D (2019) Do patent rights matter? 40 years of innovation, complexity and productivity. World Dev 115:78-93. https://doi.org/10.1016/j.worlddev.2018.10.009

Takase K, Murota Y (2004) The impact of IT investment on energy: Japan and US comparison in 2010. Energy Policy 32(11):12911301. https://doi.org/10.1016/s0301-4215(03)00097-1

Tamazian A, Chousa JP, Vadlamannati KC (2009) Does higher economic and financial development lead to environmental degradation: evidence from BRIC countries. Energy Policy 37(1):246253. https://doi.org/10.1016/j.enpol.2008.08.025

UNECE (2020) Expanding E-government in Europe and Central Asia
Vassileva I, Wallin F, Dahlquist E (2012) Understanding energy consumption behavior for future demand response strategy development. Energy 46(1):94-100. https://doi.org/10.1016/j.energy. 2012.02.069

Verma P, Savickas R, Buettner SM, Strüker J, Kjeldsen O, Wang X (2020) Digitalization: enabling the new phase of energy efficiency. Regulatory and policy dialogue addressing barriers to improve energy efficiency, $7^{\text {th }}$ session, Geneva. Available from https:// unece.org/sites/default/files/2020-12/GEEE-7.2020.INF_.3.pdf (Accessed 18th Aug 2021)

Yang X, Khan I (2021) Dynamics among economic growth, urbanization, and environmental sustainability in IEA countries: the role of industry value-added. Environ Sci Pollut Res. https://doi.org/ 10.1007/s11356-021-16000-Z

Yang L, Li Z (2017) Technology advance and the carbon dioxide emission in China - empirical research based on the rebound effect. Energy Policy 101:150-161. https://doi.org/10.1016/j.enpol.2016. 11.020

Zahoo Z, Khan I, Hou F (2021) Clean energy investment and financial development as determinants of environment and sustainable economic growth: evidence from China. Environ Sci Pollut Res. https://doi.org/10.1007/s11356-021-16832-9

Zakari A, Khan I (2021) Boosting economic growth through energy in Africa: the role of Chinese investment and institutional quality. J Chin Econ Bus Stud. https://doi.org/10.1080/14765284.2021. 1968709

Publisher's note Springer Nature remains neutral with regard to jurisdictional claims in published maps and institutional affiliations. 